Discussion Paper No. 11-038

\title{
Religion and the Shadow Economy
}

Friedrich Heinemann and Friedrich Schneider

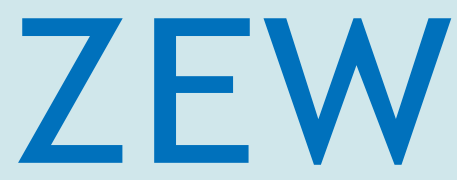

Zentrum für Europäische Wirtschaftsforschung $\mathrm{GmbH}$

Centre for European Economic Research 
Discussion Paper No. 11-038

\title{
Religion and the Shadow Economy
}

\author{
Friedrich Heinemann and Friedrich Schneider
}

Download this ZEW Discussion Paper from our ftp server:

http://ftp.zew.de/pub/zew-docs/dp/dp11038.pdf

Die Discussion Papers dienen einer möglichst schnellen Verbreitung von neueren Forschungsarbeiten des ZEW. Die Beiträge liegen in alleiniger Verantwortung der Autoren und stellen nicht notwendigerweise die Meinung des ZEW dar.

Discussion Papers are intended to make results of ZEW research promptly available to other economists in order to encourage discussion and suggestions for revisions. The authors are solely responsible for the contents which do not necessarily represent the opinion of the ZEW. 


\section{Non-technical Summary}

Religion is increasingly acknowledged to be a cultural dimension which affects economic outcomes in different regards. This contribution focuses on religion's possible impact on the size of the shadow economy. Different dimensions of the religious markets are taken into account. These dimensions refer to the overall degree of religiosity, the specific impact of different religions, religious competition or the proximity between religion and the state. For example, we would expect that the shadow economy is smaller in religious countries and in countries with a close link between religion and the state. The former is to be expected because the ethical teaching of religions imposes additional non-pecuniary costs on believers performing unlawful informal transactions. And the latter should hold because religion as an ally of the secular state should have self-interest to defend the secular partner's financial basis.

The empirical test makes use of the largest available country cross-section on the size of the shadow economy and matches this dataset with numerous religious indicators. The starting point is a baseline specification with standard economic determinants of shadow activities which then is augmented by religious indicators. We complement the analysis by a battery of robustness checks.

Overall, our findings support the view that religion influences the level of informal transactions, albeit with several qualifications. The analysis did not support the view that countries with religious citizens have smaller shadow economies per se. However, there is a significant divergence across main religions: Countries dominated by Islam or Eastern religions are associated with smaller shadow economies compared to Christian countries for comparable levels of economic development and government effectiveness. Furthermore, the proximity between state and religion is relevant whereas the degree of religious competition has no measurable impact. Close ties between the dominant religion and the state are typical for countries with a lower share of economic activity in the informal sector. Obviously, religion uses its normative influence on believers as a "supernatural police" to protect state interests if state and religion are in a reciprocal relationship. The relatively low shares of the shadow economy for Islamic countries is remarkable, given that Islamic ethics appear to be relatively skeptical on several forms of modern taxation. Obviously, the particularly close ties between religion and state in Islamic countries compensate for this. All these significant findings only hold for countries with low or middle income so that the existence of a state religion in industrial countries does not appear to be of empirical relevance in the context of the shadow economy. 


\section{Das Wichtigste in Kürze}

Religion ist eine kulturelle Dimension, deren Bedeutung für internationale Unterschiede in der ökonomischen Performance zunehmend Beachtung findet. Diese Arbeit befasst sich mit dem möglichen Einfluss der Religion auf die Größe der Schattenwirtschaft. Dabei werden verschiedene Facetten religiöser Märkte berücksichtigt: das Ausmaß der allgemeinen Religiosität, der spezifische Einfluss unterschiedlicher Religionen, die Intensität des religiösen Wettbewerbs und die Nähe zwischen Religion und Staat. Beispielsweise ist eher eine kleinere Schattenwirtschaft in Ländern mit religiöser Bevölkerung und einer großen Nähe zwischen Religion und Staat zu erwarten. Ersteres sollte gelten, weil religiös fundierte ethische Normen die nicht-pekuniären Kosten ungesetzlicher informeller Transaktionen erhöhen. Letzteres ist $\mathrm{zu}$ vermuten, weil Religionsgemeinschaften die Interessen des Staates verteidigen sollten, wenn sie sich in einer engen Partnerschaft mit diesem befinden und davon profitieren.

Die empirische Überprüfung dieser Hypothesen verwendet den derzeit größten verfügbaren Länderquerschnitt zur Größe der Schattenwirtschaft im internationalen Vergleich und verknüpft diesen mit zahlreichen religiösen Indikatoren. Ökonometrischer Ausgangspunkt ist eine Basisspezifikation, in der die Größe der Schattenwirtschaft in Abhängigkeit von zentralen ökonomischen Determinanten modelliert wird. Diese Spezifikation wird dann um die potenziellen religiösen Determinanten erweitert. Anschließend überprüfen wir die Robustheit der Schätzungen durch eine Serie von Tests.

Insgesamt zeigen unsere Ergebnisse, dass Religion das Niveau informeller Transaktionen beeinflusst, allerdings gelten Differenzierungen. So ist offenbar das Niveau der allgemeinen Religiosität nur von geringer Bedeutung. Demgegenüber zeigt sich eine signifikante Divergenz zwischen den wichtigsten Weltreligionen. Länder, die durch den Islam oder die östlichen Religionen dominiert werden, haben im Vergleich zu christlichen Ländern bei vergleichbarer ökonomischer Entwicklung und Qualität staatlicher Institutionen kleinere Schattenwirtschaften. Außerdem ist die Nähe zwischen Religion und Staat von signifikanter Bedeutung. Eine enge Beziehung zwischen beiden ist typisch für Länder mit einem geringen Anteil ökonomischer Aktivitäten im informellen Sektor. Offenbar nutzen Religionsgemeinschaften ihren normativen Einfluss auf die Gläubigen als “übernatürliche Polizei”, um staatliche Interessen zu schützen, wenn sich Staat und Religion in einer reziproken Beziehung befinden. Die vergleichsweise kleine Schattenwirtschaft in islamischen Staaten ist bemerkenswert angesichts der Skepsis islamischer Ethik gegenüber manchen modernen Formen der Besteuerung. Offenbar kompensieren dies die besonders engen Beziehungen zwischen Religion und Staat in islamischen Ländern. Die meisten dieser signifikanten Ergebnisse werden nur von den Daten für Länder mit mittlerem und niedrigem Einkommen gestützt. Die Existenz einer Staatsreligion in industrialisierten Ländern ist somit nicht von messbarer Bedeutung im Kontext der Schattenwirtschaft. 


\title{
Religion and the Shadow Economy
}

\author{
Friedrich Heinemann (ZEW Mannheim and University of Heidelberg) \\ Friedrich Schneider (University of Linz)
}

June 2011

\begin{abstract}
Religion is increasingly acknowledged to be a cultural dimension which affects economic outcomes in different regards. This contribution focuses on religion's possible impact on the shadow economy. Different dimensions of the religious markets are taken into account. These dimensions refer to the overall degree of religiosity, the specific impact of different religions, religious competition or the proximity between religion and the state. The empirical test makes use of the largest available cross-section on the size of the shadow economy and matches this dataset with numerous religious indicators. Summary measures of general religiosity or indicators of religious competition do not have a measurable impact. However, robust differences emerge across religions. Countries dominated by Islam or Eastern religions are associated with smaller shadow economies compared to Christian countries. Furthermore, the proximity between state and religion matters. Close ties between both are typical for smaller shadow economies. This is in line with the view that religion uses its normative influence to protect state interests if there is a mutually beneficial relationship.
\end{abstract}

Acknowledgement: We thank Marie-Christin Scholl and Julius Vutz for excellent research assistance.

JEL Classification: O17, O57, Z12, H26

Keywords: Economics of religion, tax morale, shadow economy

Friedrich Heinemann

ZEW Mannheim

L7, 1

68161 Mannheim

Germany

+49-621-1235 149

heinemann@zew.de
Friedrich Schneider

Department of Economics

Johannes Kepler University

4040 Linz-Auhof

Austria

+4373224688210

friedrich.schneider@jku.at 


\section{Introduction}

"Render to Caesar the things that are Caesar's, and to God the things that are God's." There is hardly a more prominent quote on the ethics of secular tax laws from a religious founder than Jesus' statement in the Gospel of Matthew (22: 21). Asked by the Pharisees whether paying taxes to the Roman emperor is lawful, Jesus points to the portrait and inscription on the coin and gives his famous reply. If statements like this were just of relevance for the internal ethical debates of religious communities, they would be without any economic relevance. However, religion leaves its mark on ethical convictions and thus may indirectly impact on economic preferences and behavior of its believers. Increasingly, the economic literature acknowledges the impact of culture in general and religion in particular on preferences and beliefs and, as a consequence, also on individual behavior like saving or education and macroeconomic outcomes, such as growth (Barro and McCleary, 2003; Cornelißen, 2006).

One particular potential effect of religion on aggregate economic outcomes, however, has so far not received any attention: Its impact on the size of the shadow economy. This is a remarkable shortcoming given that religious teachings, like the one cited above, are so explicit about the required respect for a fiscal rules of the state. Instead, the existing literature on the shadow economy (surveyed in: Schneider and Enste, 2000; Feld and Schneider, 2010) explores the determinants of the hidden economy with an overwhelming focus on economic incentives related to taxes, bureaucracy, labor markets or corruption (e.g. Friedman et al., 2000). Only few of the recent contributions look beyond the standard economic drivers: D’Hernoncourt and Méon (2008) explore the role of generalized trust in other people for a country cross-section and diagnose a robustly negative causal impact on the size of the shadow economy. The idea that religion could have an impact on the extent of informal economic activities receives some indirect backing from the literature on tax morale. Religious respondents to the World Value Survey in more than thirty countries signal higher tax morale (Torgler, 2006). This results holds independently whether religiosity is measured by membership in a religious community, attendance of services or religious education, albeit with substantial heterogeneity across different religions and confessions.

While the link between religion and (tax) ethics is an important first dimension of potential relevance for the shadow economy, the overall link is more complex. Tax evasion and shadow economic activities have a certain overlap, but the latter are also driven important factors beyond taxation such as the flight from regulation or corruption. Apart from that, religion has an impact beyond morale. Even with a comparable level of religiosity across countries, structural differences of religious markets may influence the informal sector. Religions differ with respect to their precise ethical messages and have a different degree of flexibility vis-à-vis secular laws. National conditions differ as to the closeness between religion and state. With a close alliance between both, it is more likely that religion uses its influence on the followers for the interests of the state as well. Furthermore, there is a large variance of national religious 
markets ranging from monopoly situations of one single religion up to a situation of religious pluralism. A situation of religious fractionalization may create more difficult conditions for informal transactions compared to a situation of a uniform religion. By analyzing these interlinkages, we hope to add a new dimension to the literature on the shadow economy and also expand on the economics of religion.

In the following, we first derive hypotheses regarding the expected influence of religion and religious market's specific features on the shadow economy. We then proceed by testing these hypotheses on the basis of a large cross-country sample and complement the analysis by a battery of robustness checks. It turns out that summary measures of general religiosity or indicators of religious competition do not have a measurable impact. Yet, robust differences emerge across religions. Countries dominated by Islam or Eastern religions are associated with smaller shadow economies compared to Christian countries. This effect is, however, limited to low and middle income economies. Furthermore, the proximity between state and religion matters. Close ties, e.g. through legislation based on religious doctrines, are typical for countries with a lower share of economic activity in the informal economy. Again, this result does not hold for industrial countries but is driven by the less developed economies. This is in line with the view that religion uses its normative influence to protect state interests if there is a reciprocal relationship between the state and the religious community.

\section{Religion and the market for informal transactions}

According to a broad definition (for a discussion of definitions see: Schneider et al., 2010) the shadow economy comprises those economic activities which circumvent taxation, social security contributions or bureaucratic costs related to the compliance with regulation (e.g. wage and job safety standards, statistical reporting). These activities as such may be legal; ${ }^{1}$ their concealment from public authorities, however, implies a breach of law.

Any reflection whether to conceal transactions from public authorities implies a cost-benefit calculus. On the benefit side, the migration of activities from the official to the shadow economy promises cost savings related to taxes and social security contributions. In addition, the bureaucratic burden can be reduced and legal restrictions avoided, which increases the freedom of contracts in line with the contracting parties' preferences (e.g. with respect to working hours or wages). On the cost side, the threat of pecuniary and non-pecuniary fines must be taken into account, which is a function of the size of fines and their probability. Furthermore, costs may emerge from informal transactions regularly foregoing legal protection for contrac-

\footnotetext{
${ }^{1}$ Illegal activities are a subsection of the shadow economy and include criminal activities such as burglary or drug dealing, which are usually summarized as "underground economy”.
} 
tual enforcement. Frequently, contracts in the shadow economy are informal and contractual rights are harder to defend. ${ }^{2}$

Religion may impact on this calculus in different respects: Due to any religion's moral dimension, it could influence non-pecuniary fines related to the infringement on moral norms. Religiosity may also influence the conditions for informal transactions through its possible impact on trust and trustworthiness. This general reasoning, however, has to be refined to allow for the diversity of religions and religious markets. In the following, we present these refinements in the context of different testable hypotheses.

\section{Hypothesis 1 (H1): A population's general religiosity should impact on the size of the shad- ow economy; possible counteracting effects leave the sign expectation unclear.}

Ethical convictions affect individual utility maximization. Subjects with ethical sensitivities face specific non-pecuniary fines with respect to transgressions. Transgressions can then create a feeling of bad conscience, guilt, shame or embarrassment, and can impair positive feelings, such as self-esteem or a sense of integrity (Grasmick and Bursik, 1990). The prediction from neoclassical economic reasoning is clear: The existence of a moral norm should reduce the level of individual activity which is deemed to be immoral by the respective individual. ${ }^{3}$ This augmentation of utility maximization is successfully applied in different contexts: Tax compliance is positively influenced by taxpayers' ethical attitudes (Reckers et al., 1994; Andreoni et al., 1998); disincentives of the welfare state depend on ethical norms related to the honesty of welfare recipients (Lindbeck, 1995; Lindbeck et al., 1999); or the prevalence of crime is affected by a society's ethical standards (Grasmick and Bursik, 1990).

What holds for ethical norms in general may even have a stronger behavioral effect if these norms have a religious foundation. Already Adam Smith, in his "Theory of Moral Sentiments", points to the ethical motivation caused by the religious belief in an "all-seeing Judge" and "a life to come" (Iannaccone, 1998: 1478). Thus, religion expands the universe of nonpecuniary sanctions up to extreme fines, such as "hell” and "eternal condemnation”. Apart from that, religions often invest heavily into the education of their believers and monitor their behavior (Iannaccone, 1992, 1998). Importantly, the normative impact of religion may reach beyond its immediate followers. Ethical norms which have a religious past and origin may survive even if a society becomes largely atheist. Furthermore, religious persons' behavioral

\footnotetext{
${ }^{2}$ There may be alternatives to legal enforcement, such as social pressure or even unlawful types of pressure like threat of violence. However, these types of enforcement mechanisms regularly imply higher costs and uncertainties compared to standard mechanisms of legal protections.

${ }^{3}$ It should be stressed that this conscience constrained utility maximization should generally not be expected to result in a zero level of immoral activity. The marginal moral costs of the activity will be equalled to the marginal utility from the immoral activity with equilibrium well possible in the positive range of shadow activities.
} 
example can influence non-believers: In the context of religion and crime, Hull (2000) finds that religious rules against crime also affect a community's non-religious inhabitants. Overall, there is a rich empirical literature supporting the view that religion indeed has a dampening effect on phenomena like crime, suicide or drug and alcohol use (surveyed in: Iannaccone, 1998; McCullough and Willoughby, 2009).

Although different religions may put different emphases on the issue (see below), activities in the shadow economy should generally have a negative valuation by religions' ethical standards. All world religions stress the importance of norms related to honesty, truthfulness and altruism. For example, the Ten Commandments, which are of authority for Jews and all Christian denominations alike, oblige not to steal or bear a false witness. Clearly, informal activities imply dishonesty (against the state) and damage for the state and the community and could be classified as a specific modern variant of theft. Therefore, the first straightforward expectation is that more religious countries should have smaller shadow economies.

One additional possible impact of religiosity on the shadow economy, however, must be taken into consideration. The ethical obligation of religious people to act truthfully may render the costs of informality in terms of lacking legal contract enforcing low. Religion and its ethical constraints on transaction partners may offer a substitute for legal protection of (informal) contracts. Religion could then, through its effect on the trustworthiness of market participants, foster transactions in the shadow economy. If this effect outweighs the ethical effects, religiosity may be positively correlated with informal transactions. Thus, there is an unclear sign prediction for the overall effect of a population's degree of religiosity.

Religiosity has countless different appearances. As a consequence, the preceding general hypothesis requires qualifications. Particular religions differ with respect to their view on the secular state and their conviction of a moral duty to comply with this state's rules. The following hypothesis reflects this insight.

\section{Hypothesis 2 (H2): The size of the shadow economy should differ across countries depend- ing on the specific type of religion.}

While a comprising comparative analysis of main religions' position towards the fiscal laws of the modern state would be an ambitious interdisciplinary undertaking and, as such, beyond the scope of our analysis, a few short remarks on a range of important world religions are helpful.

\section{Jewish Orthodoxy}

The perspective of Jewish orthodoxy on the respect of a state's rule in general and tax rule in particular are rather strict. According to Cohn (1998), Jews have a duty to follow their coun- 
try's statutes. Exceptions might only be possible if the government is based on brute force. The laws of secular democracies, however, have to be respected. Moreover, evading taxes would contradict Jewish ethics because it implies lying and because for a Jewish orthodox any behavior which could discredit his religion is prohibited. Finally, secular sanctions, like being imprisoned, also have a religious dimension since they limit the possibility to properly practice Judaism and must therefore be avoided (for a critical view on these views: McGee, 2006).

\section{Catholicism}

The biblical message for the Christian ethics of the shadow economy is unequivocal given the authority of the Ten Commandments and Jesus' prominent statement with respect to the issue of tax evasion as cited at the outset. In the fiscal respect, the Roman Empire with its exhaustive system of tax collection can be regarded as a predecessor to the modern fiscal state. Against this background, the Christian New Testament clearly points the way towards a critical ethical view on non-compliance with the legal rules of the modern welfare and tax state. In its official Catechism from 1993, the Catholic Church (Vatican, 1993) summarizes its current ethical teaching with an interpretation of the Seventh Commandment ("You shall not steal") and extends this obligation to public property and revenues. It explicitly mentions tax evasion as "morally illicit" (Nb. 2409) and criticizes the second important dimension of informal economic activities ("it is unjust not to pay the social security contributions required by legitimate authority”, Nb. 2436).

\section{Orthodox Christianity}

In the Eastern Orthodox tradition there is a strong tradition of close ties between the church and the state (Mavrogordatos, 2000). In this tradition "God is Caesar's junior partner" (Huntington, 1997: 70), which stands in contrast to the course of the Western Church, and offenses against the state were also religious offenses (Torgler, 2006). However, most orthodox countries have been subject to the anti-religious suppression in the Communist era, an experience which might have permanently weakened the mental power of this past alliance.

\section{Protestantism}

The specific economic preferences of the Protestant denominations within Christianity have been in the interest of research at least since Max Weber's “The Protestant Ethic and the Spirit of Capitalism” from 1904. Weber ascribes to Protestantism a particular work ethic and, recently (Becker and Woessmann, 2009), particularly heavy investment into human capital benefitting development and growth. The conclusions with respect to the ethics of the shadow economy are more difficult to draw, not least because Protestantism has no single top authori- 
ty like the Catholic Church which would be able to define its official teaching. Based on Luther's writing, however, one can argue that Protestantism fosters the respect of the secular state. In Luther's famous doctrine of the "Two Kingdoms" (Whitford, 2005), the reformer differentiates between the secular ("the Law") and the religious kingdom ("the Gospel”) with its specific obligations. He acknowledges the necessity of the law, which limits chaos and evil. Luther thus prepares the ground for the autonomy of and respect for the rules of the secular state as long as this state does not infringe on the religious sphere. In addition, in line with Weber's views, one could argue that Protestants should support the success of modern capitalism including its rules on taxes, the welfare state and other regulations. There is, however, a specific counter-argument: People with a Protestant work ethic tend to believe in hard work and personal effort and could thus be less likely to accept taxes or social security contributions related to redistribution. Furnham (1983) finds experimental evidence that Protestant work ethics often result in an opposition to taxes.

Islam

According to McGee's survey (1997), Islamic ethics imply a differentiated ethical view with respect to modern types of taxes. While the payment of Zakat (a small percentage of wealth for the poor and needy) is a religious obligation, the government has a limited legitimacy to raise taxes. Several tax types are not legitimate, such as taxes which increase consumer prices or an inheritance tax. Proportionate taxes due to their similarity to the proportionate Zakat are easier to defend compared to progressive taxes. Neither is the non-compliance with certain government regulations always deemed to be immoral. This applies to certain trade regulations which only benefit a limited number of people or which actually harm the general public. It is obvious that these kinds of religious reservations against certain types of regulation and important pillars of many modern tax systems might also imply a more relaxed view on informal transactions.

\section{Buddhism and Hinduism}

The fundamental aim of Buddhism is salvation, which means to enter the Nirvana by exiting the cycle of rebirth (Keown, 2005). The future existence in the cycle of rebirth is determined by the collected Karma. Good actions lead to good Karma whereas bad actions lead to bad Karma. Actions which evolve from greed, hatred and delusion are considered bad. In contrast, actions which evolve from non-attachment, benevolence and understanding are considered good. A virtue which is considered highly important by Buddhists is generosity. Thus, Buddhist ethics propagate altruistic behavior by despising greed or dishonesty and denying an overemphasis on one's own well-being. It appears obvious that all this should imply a negative view on shadow economy activities. 
Basic principles of Hinduism are, amongst others, the belief in the cycle of rebirth (and the possible exit through salvation), the belief in Karma theory and the caste system (Becke, 1996). With these considerations in mind, a similar argument to the one made with Buddhism is applicable. Possibly, the view that an individual's social position ("caste") is predetermined could be linked to a more critical view on redistributive taxation which does not respect the given order.

Of course, any such attempt to briefly characterize the rich facets of different religions' ethical views relevant for the shadow economy must remain highly superficial. However, even this very brief discussion supports the expectation that not only religion as such but also the specific type of religion could be relevant for the size of the shadow economy. An empirical testing strategy should reflect this insight. Torgler (2006) is an important example for such an approach. In his empirical scrutiny of religion and tax morale based on individual crosssection data from the World Value Survey, he finds that Catholics, Hindus and Buddhists have higher tax morale than people without a religious denomination. Orthodox Christians and Protestants show lower tax morale compared to their non-religious compatriots whereas Jews and Moslems do not differ significantly.

Beyond the specific normative contents of a religious community, the characteristics and the degree of competition of the national religious market may matter. This leads us to the third hypothesis:

\section{Hypothesis 3 (H3): The size of the shadow economy should be related to the fragmentation of the market shares of religions with an unclear sign prediction.}

The degree of religious fragmentation and competition could matter in several respects. On the one hand, with one dominant religion the state has one single potential ally for any strategy to enforce state rules also through religious assistance. With religious fragmentation any such alliance is more difficult to achieve.

On the other hand, a monopolistic situation of one religious supplier could result in less efficiency in providing religious services and influencing social norms. Religious pluralism offers a wider choice for the population and thus a better fit to the diverse religious needs. The link between religious competition and religious activity has attracted considerable attention in the empirical literature on the economics of religion. Several authors find that competition results in higher religious participation (Finke and Iannaccone, 1993; for a survey on that literature see Sherkat and Ellison, 1999; Barro and McCleary, 2003), with opposing views from Olson (1999) and Voas (2002). If the link actually exists, we expect that low religious diversity should rather weaken religion's power to control people and to influence their social norms. 
Both mentioned effects are countervailing so that we do not have a clear sign expectation for the impact of religious fragmentation.

A further dimension of a religious market relates to the formal ties between religion and the state. This leads us to the fourth hypothesis.

\section{Hypothesis 4 (H4): Countries with an established state church should have smaller shadow economies.}

The relation between religious organizations and the state can range from deep mutual hostility up to almost identity in the case of the state being based on religious laws and religious leaders endowed with secular power. We would expect that the willingness of religious authority to protect the property and interests of the state is influenced by the proximity between both. A state religion which enjoys diverse financial and regulatory privileges under protection from secular authorities should have an institutional self-interest to defend this state. Therefore, we would expect such a religion to also use its normative teaching, monitoring and sanctioning of followers for supporting fiscal rules and government regulation. Religion as a "supernatural police" (Anderson and Tollison, 1992) should be most active in the interest of the state if it stands in a close reciprocal relationship to the latter.

\section{Data and Econometric Results}

\subsection{Data sources}

For the size of the shadow economy, we make use of the data for 162 countries from Schneider, Buehn and Montenegro (2010: Table 2). The authors base their calculations on a Multiple Indicators Multiple Causes (MIMIC) model $^{4}$, which is a particular type of a structural equations model. The shadow economy is treated in this approach as a latent variable for which information is available through two types of observables, namely causal and indicator variables. Causal variables relate to the factors which explain the existence and growth of the shadow economy (e.g. fiscal burden on official transactions, regulation). Indicator variables measure phenomena related to shadow activities, such as the increased circulation of cash. A characteristic limitation of the MIMIC approach is that it only provides relative, not absolute, estimates of the size of the shadow economy. Additional calibration procedures are required in order to calculate absolute values of the size of the shadow economy. This limitation, how-

\footnotetext{
${ }^{4}$ For methodological details and a brief survey of the recent MIMIC-based shadow economy literature see Schneider, Buehn and Montenegro (2010).
} 
ever, is less of a concern in this study's context where we are not particularly interested in the absolute size of shadow economies but rather in their international variance.

As (economic) determinants of informal transactions, we take account of factors related to the general level of a country's economic development, job opportunities in the official labor market, incentives related to regulation, corruption or taxation. Therefore, we include the following measures as standard determinants into our baseline: Real GDP per capita, unemployment rate, government effectiveness, size of government, business freedom, fiscal freedom and freedom from corruption (this specific choice is also driven by data restrictions inherent to a large country including many low income economies; for details and summary statistics see appendix).

For religious data we make use of several data sources. The Religion and State Project (RAS) provides information on the relationship between religion and the state in more than 170 countries. This project is located at Bar-Ilan University. Its goal is to provide measures which quantify the link between government and religion, but it also offers a rich set of more general religious indicators. ${ }^{5}$ The RAS project covers all countries with a population of at least 250.000 in the year 2000 as well as Western Democracies with lower populations. Data comprise a time span between 1990 and 2002; 6 population statistics, however, are only available on a cross-section basis with observations around the year 2000. Sources for the RAS database are human rights reports and academic as well as news media sources (Fox, 2004). The RAS database is complemented by the data set collected by Fox and Tabory (2008) in the context of their study dealing with the impact of state regulation of religion on religious participation and belief. Finally, we also employ survey results from Gallup World, which are used for the cross-section quantification of overall religiosity over a large set of countries.

The low time variance of religious phenomena in addition to the lacking availability of time series of religious population data limit any empirical approach to cross-section analyses. In the following testing of the four key hypotheses, we include the following rich set of religious indicators (see Table 1 for descriptive statistics and Table A-1 in the appendix for exact definitions and sources).

\footnotetext{
${ }^{5}$ For further details on the Religion and State Project see www.thearda.com/ras/.

${ }^{6}$ States which became independent during that time were included beginning in the year of independence and those states in a state of Civil War were included as soon as a functioning government was in place again.
} 
Table 1: Summary statistics religious variables

\begin{tabular}{|c|c|c|c|c|c|}
\hline Variable & $\begin{array}{l}\text { Number } \\
\text { of obser- } \\
\text { vations }\end{array}$ & Mean & $\begin{array}{l}\text { Standard } \\
\text { deviation }\end{array}$ & Min & Max \\
\hline \multicolumn{6}{|c|}{ General religiosity } \\
\hline Religion important (population share in \%), Gallup & 149 & 72.09 & 25.62 & 12.00 & 99.00 \\
\hline Attending weekly (population share in \%), Gallup & 148 & 49.60 & 22.31 & 10.00 & 93.00 \\
\hline $\begin{array}{l}\text { Confidence in religious organization (population share } \\
\text { in \%), Gallup }\end{array}$ & 139 & 69.41 & 16.82 & 24.00 & 95.00 \\
\hline Gallup religiosity indicator & 135 & 63.93 & 20.17 & 22.00 & 92.60 \\
\hline $\begin{array}{l}\text { Attending monthly (population share in \%), } \\
\text { WVS/ISSP }\end{array}$ & 80 & 39.67 & 24.67 & 3.10 & 95.20 \\
\hline Attending weekly (population share in \%), WVS/ISSP & 80 & 36.07 & 28.86 & 2.20 & 99.10 \\
\hline $\begin{array}{l}\text { Considering oneself religious (population share in \%), } \\
\text { WVS/ISSP }\end{array}$ & 70 & 70.95 & 19.68 & 14.70 & 98.60 \\
\hline \multicolumn{6}{|c|}{ Specific religions } \\
\hline Christian population share in \% & 171 & 51.61 & 37.76 & 0.00 & 99.30 \\
\hline Islam population share in \% & 166 & 27.94 & 37.04 & 0.00 & 99.80 \\
\hline Other religions' population share in \% & 160 & 16.79 & 24.86 & 0.00 & 98.80 \\
\hline Non-religious population share in \% & 155 & 5.25 & 12.83 & 0.00 & 98.00 \\
\hline \multicolumn{6}{|c|}{ Religious fragmentation and competition } \\
\hline Population share majority religion in \% & 174 & 68.53 & 21.48 & 22.80 & 100.00 \\
\hline Herfindahl index religions’ population shares & 81 & 0.56 & 0.23 & 0.18 & 0.97 \\
\hline Dummy established state religion & 174 & 0.26 & 0.44 & 0.00 & 1.00 \\
\hline \multicolumn{6}{|c|}{ Closeness between religion and state } \\
\hline $\begin{array}{l}\text { Composite indicator on closeness between religion } \\
\text { and state }\end{array}$ & 174 & 23.89 & 16.71 & 0.00 & 77.56 \\
\hline Dummy religious laws influence legislation & 174 & 0.20 & 0.40 & 0.00 & 1.00 \\
\hline Indicator discrimination against minority religions & 174 & 5.49 & 7.56 & 0.00 & 38.00 \\
\hline Dummy mandatory religious education & 174 & 0.18 & 0.38 & 0.00 & 1.00 \\
\hline $\begin{array}{l}\text { Dummy government collects taxes on behalf of reli- } \\
\text { gious organizations }\end{array}$ & 174 & 0.09 & 0.29 & 0.00 & 1.00 \\
\hline Dummy government funding of clergy & 174 & 0.28 & 0.45 & 0.00 & 1.00 \\
\hline
\end{tabular}




\section{Indicators related to $\mathrm{H} 1$ and religiosity in general}

H1 relates to religiosity in general independent from a country's specific religious situation. Available indicators relate to religious practice as pursued through the regular attendance of religious services or the visit of places of worship. In addition, the individual's subjective assessment of the importance of religion for one's own life offers an alternative unrelated to physical presence at places like churches, mosques or other places of worship. Relevant survey results originate from two different sources: The World Value Survey and Gallup World. In addition, the estimations include the Gallup World Religiosity Index as a composite indicator which is based on three dimensions: The attendance of religious services, confidence in religious communities and the importance assigned to religion (for the precise definition and source of data see Table A-1 in the appendix).

\section{$\underline{\text { Indicators related to } \mathrm{H} 2 \text { and specific religions }}$}

For testing the impact of a specific religion, the RAS classification of countries according to their majority religions is the starting point. Two different levels of aggregation are employed which are also guided by the empirical necessity to avoid too small classes (see Table 2). Of course, any such classification has several shortcomings. The within class homogeneity is highly different: While Catholicism and its ethical teaching is highly centralized on a global level, this is already very different for Protestantism or Orthodox Christianity with their decentralized structures. The within heterogeneity is, obviously, extreme for the "other"category. Furthermore, the classification according to majority religions hides the fact that the degree of majority may differ between a truly uniform religious denomination of a country's population and a rather diversified religious market where, however, one religion has a (thin) majority. Therefore, we include the continuous shares of main religions, which is only available from the RAS database for a high aggregation (Christian, Islam, and “Other”), as an alternative measure in the test. 
Table 2: Classifications of countries according to majority religion

\begin{tabular}{|c|c|c|c|c|c|}
\hline \multicolumn{2}{|c|}{$\begin{array}{l}\text { Second aggregation } \\
\text { ("broad differences”) }\end{array}$} & \multicolumn{2}{|l|}{$\begin{array}{l}\text { First aggregation } \\
\text { (“fine differences”) }\end{array}$} & \multicolumn{2}{|l|}{ RAS classification } \\
\hline \multirow{4}{*}{ Christian } & \multirow{4}{*}{96} & Catholic & 43 & Catholic & 43 \\
\hline & & Orthodox & 12 & Orthodox & 12 \\
\hline & & Protestant & 16 & Protestant & 16 \\
\hline & & Christian (general) & 25 & Christian (general) & 25 \\
\hline \multirow{4}{*}{ Islam } & \multirow{4}{*}{46} & \multirow{4}{*}{ Islam } & \multirow{4}{*}{46} & Islam, Sunni & 34 \\
\hline & & & & Islam, Shi’i & 3 \\
\hline & & & & Islam, other & 1 \\
\hline & & & & Islam (general) & 8 \\
\hline \multirow{6}{*}{ Other } & \multirow{6}{*}{32} & \multirow{2}{*}{ Buddhist or Hindu } & \multirow{2}{*}{10} & Buddhist & 8 \\
\hline & & & & Hindu & 2 \\
\hline & & \multirow{4}{*}{ Other } & \multirow{4}{*}{22} & Jewish & 1 \\
\hline & & & & Animist & 4 \\
\hline & & & & Other & 5 \\
\hline & & & & Mixed & 12 \\
\hline Total & 174 & & 174 & & 174 \\
\hline
\end{tabular}

Indicators related to $\mathrm{H} 3$ and to religious fragmentation and competition

Different alternatives are employed to depict a country's religious diversity. First, we make use of the Herfindahl index, which was calculated on the basis of population data and religious shares from the World Christian Encyclopedia (Fox and Tabory, 2008). It is above 0.9 for several countries with a Muslim population (Morocco, Turkey, Algeria, Pakistan, Iran), but some Christian countries also reach levels above 0.8 (e.g. Malta, Poland, Greece, Spain). As an alternative, the population percentage share of the largest religion is used. This rather measures the power of the dominant religious player than describing the overall competitive situation like the Herfindahl index. Finally, an important dimension of religious competition is state intervention in the religious market. To control for this aspect of (reduced) competition, we employ a dummy variable which equals one if there is an established religion benefitting from state protection as the official religion of a country. 


\section{Indicators related to $\mathrm{H} 4$ and to the closeness of religion and state}

The links between (the dominant) religion and the state is quantified along different dimensions through the RAS indicators. We include several of these dimensions with a particular appeal for the question under scrutiny into our testing. One of the country dummies is equal to one if a country's legislation is classified as "substantially religious" or the religious law is even state law. In this case, state laws should clearly have a substantial religious authority in the realm of taxation as well. Further dummies identify countries where religious education is mandatory in public schools, where the government collects taxes on behalf of religious organizations or where the clergy is at least partially funded by the government. Whereas mandatory religious education simplifies the normative impact of religion on the population, religious tax collection and tax financed clergy underline the self-interest of religious organizations in suppressing shadow activities. Two additional composite indicators are used: One measures the degree to which the state discriminates against minority religions and thus protects the dominant religion in a particularly aggressive way. The expectation is that the dominant religion should, in exchange for this protection, protect the government's interests. Finally, the overall indicator on the closeness between religion and state, which combines all aspects included in the RAS project, ${ }^{7}$ is used as well.

\subsection{Descriptive Analysis}

Figure 1 relates to the first hypothesis and the impact of religiosity in general. Countries are classified into the deciles of the Gallup indicator of religiosity. Clearly, less religious countries have smaller GDP shares of informal transactions.

\footnotetext{
${ }^{7}$ The composite RAS indicator includes the following dimensions: Official support or suppression of main religion and of minority religions, religious regulation and restrictions, and the extent of legislation based on religious doctrines; for details see Fox (2004).
} 
Figure 1: General religiosity and size of the shadow economy

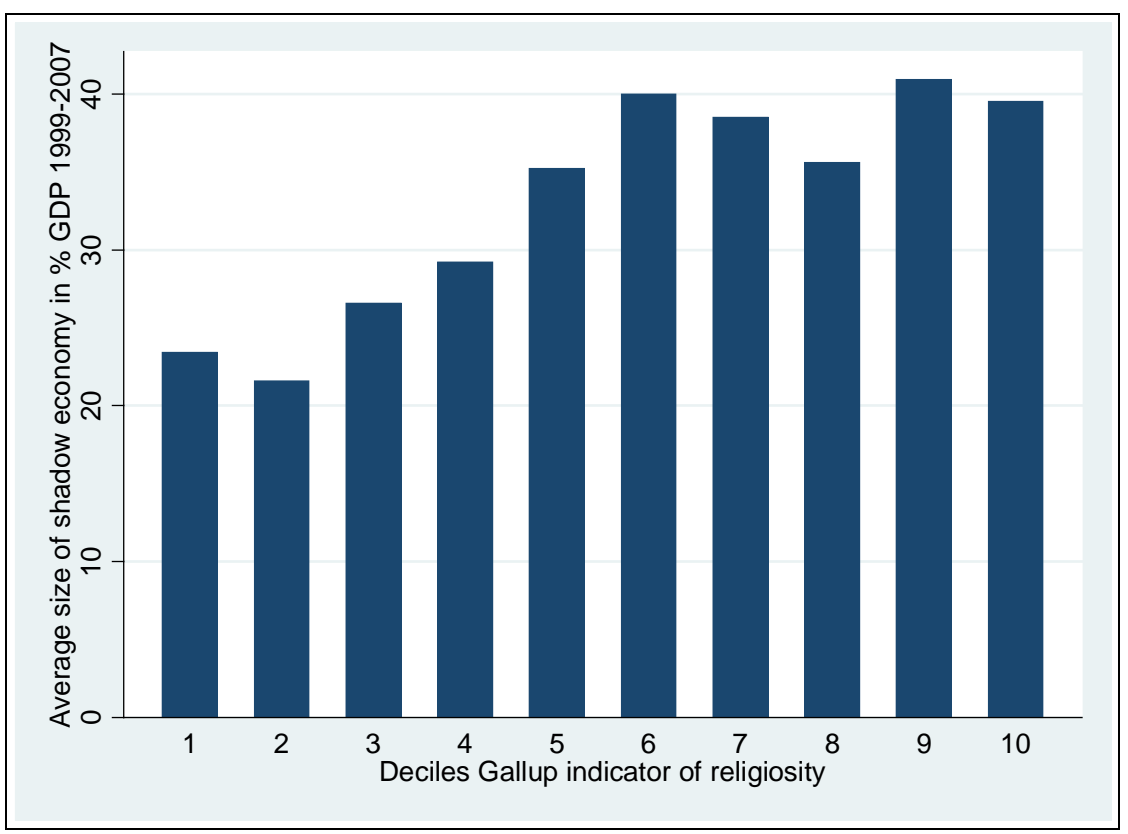

Figure 2 presents the mean size of the shadow economy for countries classified according to their majority religions. Most classes have similar means between 30 and $35 \%$ of GDP. The only cases divergent from this simple comparison are countries dominated by Orthodox and Protestant Christians with the former having larger and the latter lower shadow economies compared to the other religious groupings.

Figure 2: Dominant religion and the size of shadow economy

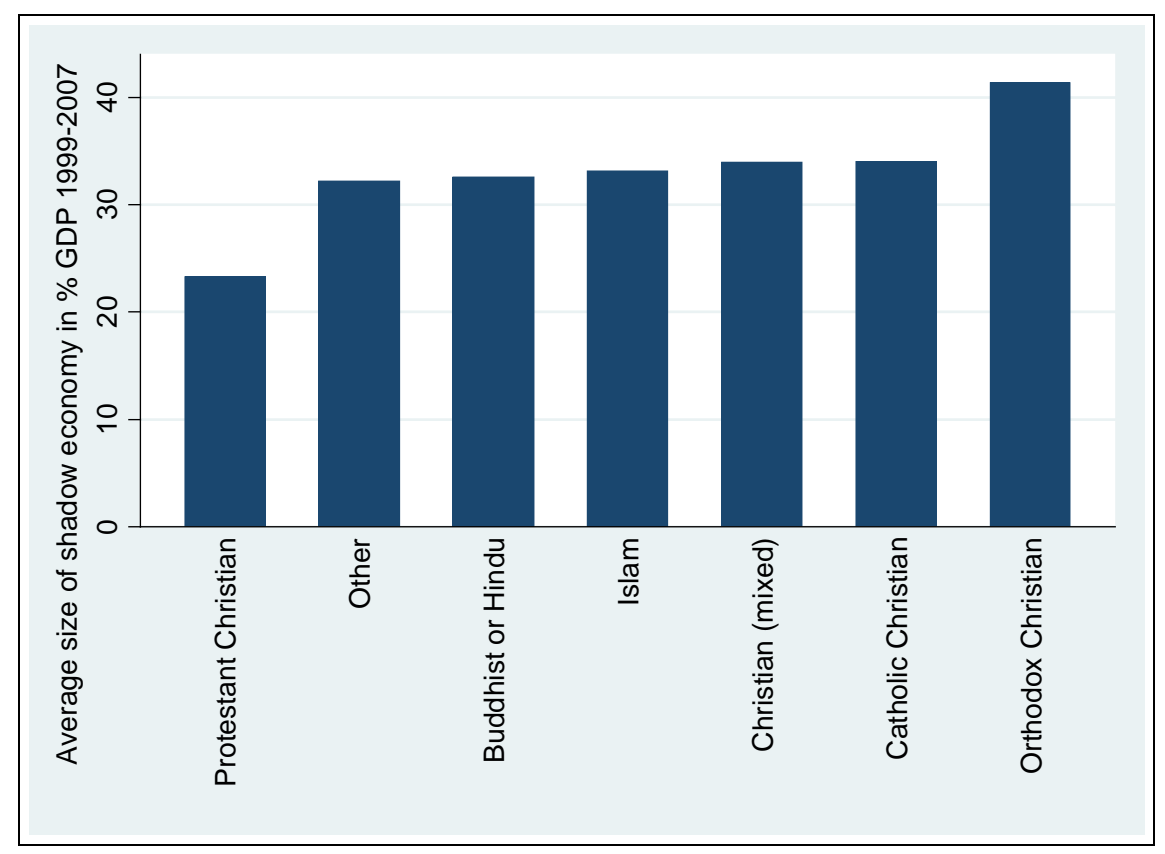


Findings for religious competition according to Hypothesis 3 are mixed: No clear correlation between the Herfindahl index of the religious markets and the size of the shadow economy is detectable (Figure 3). However, Figure 4 indicates that countries with an established state religion indeed have fewer shadow activities.

Figure 3: Religious competition and the size of the shadow economy

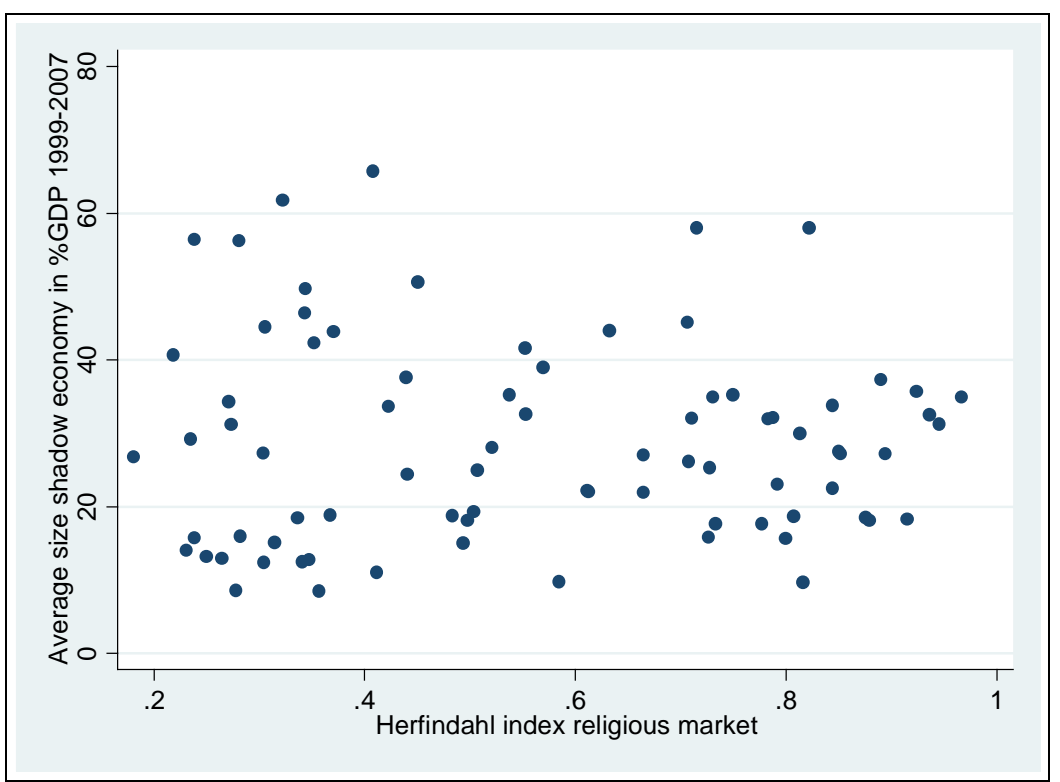

Figure 4: State religion and the shadow economy

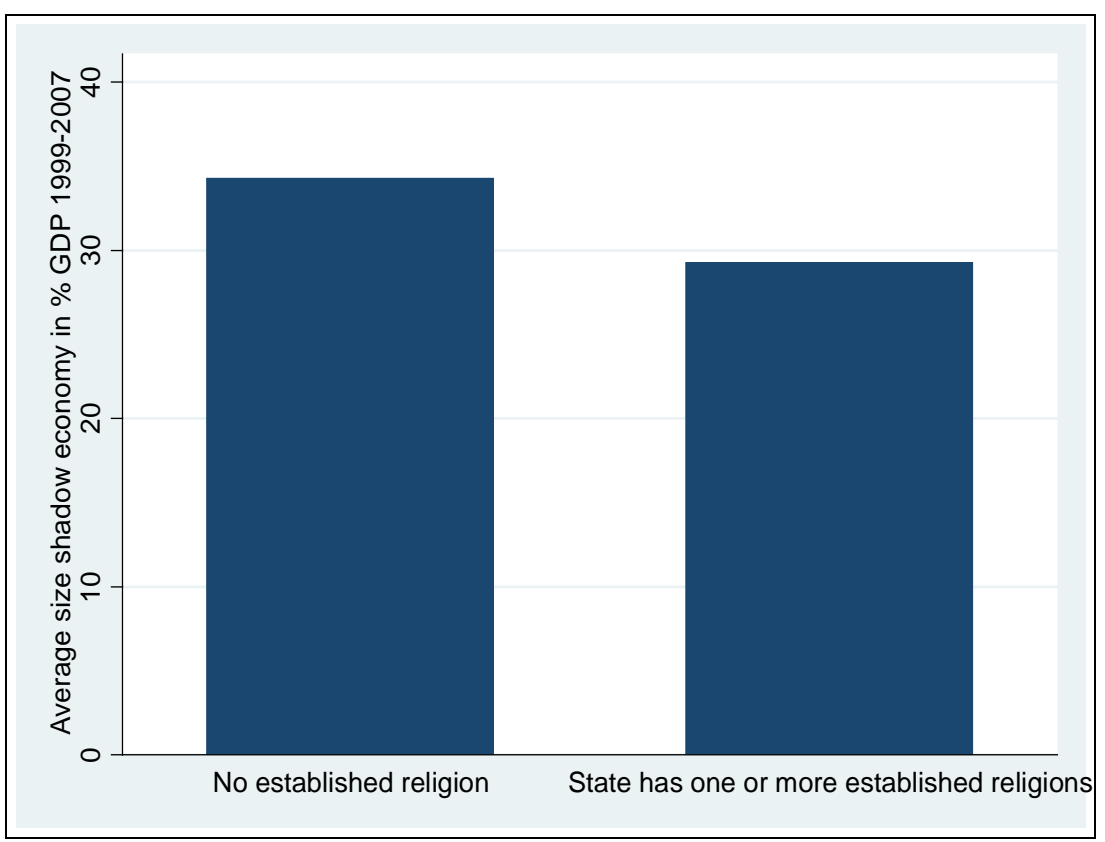


The final descriptive country classification looks for the empirical content of Hypothesis 4. A similar impression originates from the composite RAS indicator on the proximity between religion and the state. The country groups in the two top deciles of the indicator are characterized both by a particular strong link between religious and secular powers and, at the same time, relatively small shadow-GDP-shares.

Figure 5: RAS indicator and the size of the shadow economy

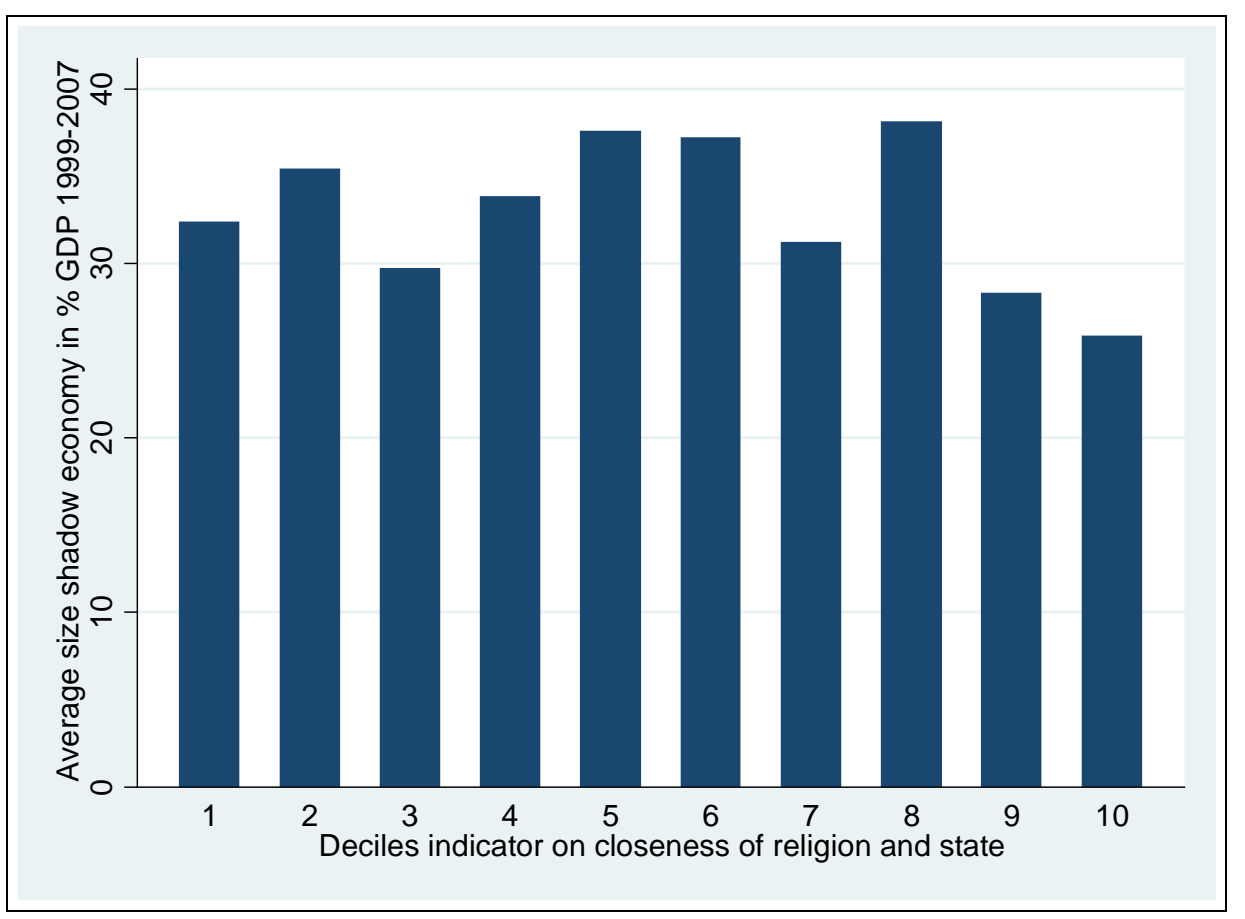

Of course, any such bivariate correlations can be highly influenced by third factors. Thus, it is well possible that the negative correlation between GDP and religiosity could be behind the pattern of Figure 1 (the correlation coefficient of GDP per capita and the indicator of religiosity is -0.52). Accordingly, we turn to the multivariate testing.

\subsection{Econometric Evidence}

The econometric cross-section testing is based on a baseline specification which includes a standard set of determinants of shadow activities as identified in the relevant literature (Table 3): The potential controls (column 1) relate to the level of economic development (GDP), government effectiveness, working opportunities in the official sector (unemployment rate), different dimensions of economic freedom representing tax and regulatory incentives for informal activities and a country's degree of corruption (for summary statistics and data sources 
see appendix). In both the baseline and the subsequent estimations, wherever available, data refers to the year 2000 or close to this reference year. A general to specific testing recommends limiting the set of controls to GDP per capita and government effectiveness (column 2). ${ }^{8}$ However, the other controls are included in the final robustness checks of our key results (see below section 3.4). Whereas the included regressions all apply OLS, we also report variants in the subsequent robustness check section. The baseline reconfirms that the size of the shadow economy is a negative function of economic development and government effectiveness.

Table 3: Baseline

\begin{tabular}{lcc}
\hline & $(1)$ & $(2)$ \\
\hline GDP per capita & $-0.364^{* * *}$ & $-0.287^{* * *}$ \\
Government effectiveness & $(0.116)$ & $(0.0936)$ \\
& $-5.332^{* * *}$ & $-6.147^{* * *}$ \\
Size of government & $(1.877)$ & $(1.209)$ \\
& 0.168 & \\
Unemployment rate & $(0.148)$ & \\
Business freedom & -0.127 & \\
& $(0.146)$ & \\
Fiscal freedom & 0.00838 & \\
& $(0.0889)$ & $(1.223)$ \\
Freedom from corruption & 0.0904 & 151 \\
& $(0.0596)$ & \\
Constant & -0.0124 & \\
& $(0.0701)$ & \\
\hline Observations & $30.05^{* * *}$ & $(6.479)$ \\
R-squared & 141 & \\
\hline Standard errors in parentheses, ${ }^{* * *} \mathrm{p}<0.01,{ }^{* *} \mathrm{p}<0.05, * 0.550$ & $\mathrm{p}<0.1$ &
\end{tabular}

To test for the consistency of the shadow data heterogeneity with Hypothesis 1, we extend the baseline to include our measures of general religiosity, still without paying any interest to cross-religion differences. We do so (Tables 4-6) for the whole sample and for samples split into high income and middle/low income countries (World Bank classification). Overall, general religiosity does not appear to be highly important to understand country heterogeneity. Only for the World Value Survey indicators (weekly church attendance and self-reported religiosity) a significant positive effect on the size of the shadow economy can be detected. This effect originates from the poorer countries' subsample. The sign points to the transaction simplifying effect of religiosity. These effects are, however, not confirmed by the similar Gallup indicators, which cover a much larger country set and, thus, cannot be regarded as robust.

\footnotetext{
${ }^{8}$ For smaller country cross-sections focussing, for example, on industrial countries, a much richer baseline could be chosen. This is, however, precluded for our extensive country set including many developing countries.
} 
Table 4: Impact of general religiosity (H1) - all countries

\begin{tabular}{|c|c|c|c|c|c|c|}
\hline & $(1)$ & $(2)$ & (3) & (4) & (5) & (6) \\
\hline GDP per capita & $\begin{array}{c}-0.368 * * * \\
(0.105)\end{array}$ & $\begin{array}{c}-0.344 * * * \\
(0.107)\end{array}$ & $\begin{array}{c}-0.339 * * * \\
(0.106)\end{array}$ & $\begin{array}{c}-0.345^{* * *} \\
(0.108)\end{array}$ & $\begin{array}{l}-0.139 \\
(0.184)\end{array}$ & $\begin{array}{l}-0.127 \\
(0.184)\end{array}$ \\
\hline Government effectiveness & $\begin{array}{c}-5.324 * * * \\
(1.476)\end{array}$ & $\begin{array}{c}-6.037 * * * \\
(1.470)\end{array}$ & $\begin{array}{l}-5.213^{* * *} \\
(1.507)\end{array}$ & $\begin{array}{c}-5.699 * * * \\
(1.581)\end{array}$ & $\begin{array}{l}-6.803^{* * *} \\
(2.334)\end{array}$ & $\begin{array}{c}-7.003 * * * \\
(2.375)\end{array}$ \\
\hline $\begin{array}{l}\text { Attendance religious service } \\
\text { (Gallup) }\end{array}$ & $\begin{array}{c}0.020 \\
(0.043)\end{array}$ & & & & & \\
\hline $\begin{array}{l}\text { Confidence in Religion } \\
\text { (Gallup) }\end{array}$ & & $\begin{array}{l}-0.004 \\
(0.057)\end{array}$ & & & & \\
\hline $\begin{array}{l}\text { Religion important } \\
\text { (Gallup) }\end{array}$ & & & $\begin{array}{c}0.038 \\
(0.040)\end{array}$ & & & \\
\hline $\begin{array}{l}\text { Religiosity Index } \\
\text { (Gallup) }\end{array}$ & & & & $\begin{array}{c}0.0120 \\
(0.0539)\end{array}$ & & \\
\hline $\begin{array}{l}\text { Weekly attendance } \\
\text { (WVS) }\end{array}$ & & & & & $\begin{array}{l}0.1374 * * * \\
(0.040)\end{array}$ & \\
\hline $\begin{array}{l}\text { Consider oneself religious } \\
\text { (WVS) }\end{array}$ & & & & & & $\begin{array}{l}0.103^{*} \\
(0.058)\end{array}$ \\
\hline Constant & $\begin{array}{c}37.05^{* * *} \\
(2.444) \\
\end{array}$ & $\begin{array}{c}38.39 * * * \\
(4.151)\end{array}$ & $\begin{array}{c}34.82 * * * \\
(3.181)\end{array}$ & $\begin{array}{c}37.20^{* * *} \\
(3.692)\end{array}$ & $\begin{array}{c}29.76^{* * *} \\
(2.772) \\
\end{array}$ & $\begin{array}{c}26.11^{* * * *} \\
(4.872)\end{array}$ \\
\hline Observations & 131 & 125 & 132 & 124 & 77 & 67 \\
\hline R-squared & 0.568 & 0.578 & 0.553 & 0.567 & 0.608 & 0.564 \\
\hline
\end{tabular}

\section{Table 5: Impact of general religiosity (H1) - high income}

\begin{tabular}{|c|c|c|c|c|c|c|}
\hline & $(1)$ & $(2)$ & (3) & $(4)$ & $(5)$ & (6) \\
\hline GDP per capita & $\begin{array}{c}-0.204^{* *} \\
(0.086)\end{array}$ & $\begin{array}{c}-0.206^{* *} \\
(0.089)\end{array}$ & $\begin{array}{c}-0.236^{* * *} \\
(0.082)\end{array}$ & $\begin{array}{c}-0.229 * * \\
(0.088)\end{array}$ & $\begin{array}{c}-0.307^{* *} \\
(0.129)\end{array}$ & $\begin{array}{c}-0.312^{* *} \\
(0.125)\end{array}$ \\
\hline Government effectiveness & $\begin{array}{c}-5.504^{* * *} \\
(1.721)\end{array}$ & $\begin{array}{c}-5.168 * * * \\
(1.459)\end{array}$ & $\begin{array}{l}-4.461 * * \\
(1.814)\end{array}$ & $\begin{array}{c}-4.610^{* *} \\
(1.778)\end{array}$ & $\begin{array}{l}-3.855^{*} \\
(2.085)\end{array}$ & $\begin{array}{l}-3.108 \\
(2.049)\end{array}$ \\
\hline $\begin{array}{l}\text { Attendance religious service } \\
\text { (Gallup) }\end{array}$ & $\begin{array}{l}-0.018 \\
(0.055)\end{array}$ & & & & & \\
\hline $\begin{array}{l}\text { Confidence in Religion } \\
\text { (Gallup) }\end{array}$ & & $\begin{array}{c}-0.003 \\
(0.063)\end{array}$ & & & & \\
\hline $\begin{array}{l}\text { Religion important } \\
\text { (Gallup) }\end{array}$ & & & $\begin{array}{c}0.022 \\
(0.043)\end{array}$ & & & \\
\hline $\begin{array}{l}\text { Religiosity Index } \\
\text { (Gallup) }\end{array}$ & & & & $\begin{array}{c}0.026 \\
(0.061)\end{array}$ & & \\
\hline $\begin{array}{l}\text { Weekly attendance } \\
\text { (WVS) }\end{array}$ & & & & & $\begin{array}{c}0.002 \\
(0.047)\end{array}$ & \\
\hline $\begin{array}{l}\text { Consider oneself religious } \\
\text { (WVS) }\end{array}$ & & & & & & $\begin{array}{c}0.067 \\
(0.048)\end{array}$ \\
\hline Constant & $\begin{array}{c}33.36 * * * \\
(3.080)\end{array}$ & $\begin{array}{c}32.55^{* * *} \\
(3.711)\end{array}$ & $\begin{array}{c}31.16^{* * *} \\
(3.514)\end{array}$ & $\begin{array}{c}31.05^{* * *} \\
(3.799) \\
\end{array}$ & $\begin{array}{c}33.07 * * * \\
(2.569) \\
\end{array}$ & $\begin{array}{c}27.82 * * * \\
(4.236) \\
\end{array}$ \\
\hline Observations & 43 & 41 & 43 & 41 & 36 & 35 \\
\hline R-squared & 0.542 & 0.526 & 0.543 & 0.529 & 0.575 & 0.582 \\
\hline
\end{tabular}


Table 6: Impact of general religiosity (H1) - middle and low income

\begin{tabular}{|c|c|c|c|c|c|c|}
\hline & $(1)$ & $(2)$ & (3) & (4) & (5) & (6) \\
\hline GDP per capita & $\begin{array}{l}-0.652 \\
(0.458)\end{array}$ & $\begin{array}{c}-0.828 \\
(0.520)\end{array}$ & $\begin{array}{l}-0.474 \\
(0.470)\end{array}$ & $\begin{array}{l}-0.701 \\
(0.539)\end{array}$ & $\begin{array}{c}0.541 \\
(0.675)\end{array}$ & $\begin{array}{c}0.053 \\
(0.709)\end{array}$ \\
\hline Government effectiveness & $\begin{array}{l}-3.561 \\
(2.405)\end{array}$ & $\begin{array}{l}-3.705 \\
(2.602)\end{array}$ & $\begin{array}{l}-4.374 * \\
(2.446)\end{array}$ & $\begin{array}{l}-3.920 \\
(2.637)\end{array}$ & $\begin{array}{l}-12.29 * * * \\
(4.488)\end{array}$ & $\begin{array}{c}-11.70^{* *} \\
(5.121)\end{array}$ \\
\hline $\begin{array}{l}\text { Attendance religious service } \\
\text { (Gallup) }\end{array}$ & $\begin{array}{c}0.007 \\
(0.061)\end{array}$ & & & & & \\
\hline $\begin{array}{l}\text { Confidence in Religion } \\
\text { (Gallup) }\end{array}$ & & $\begin{array}{c}-0.098 \\
(0.092)\end{array}$ & & & & \\
\hline $\begin{array}{l}\text { Religion important } \\
\text { (Gallup) }\end{array}$ & & & $\begin{array}{c}0.031 \\
(0.062)\end{array}$ & & & \\
\hline $\begin{array}{l}\text { Religiosity Index } \\
\text { (Gallup) }\end{array}$ & & & & $\begin{array}{l}-0.049 \\
(0.085)\end{array}$ & & \\
\hline $\begin{array}{l}\text { Weekly attendance } \\
\text { (WVS) }\end{array}$ & & & & & $\begin{array}{c}0.219 * * * \\
(0.063)\end{array}$ & \\
\hline $\begin{array}{l}\text { Consider oneself religious } \\
\text { (WVS) }\end{array}$ & & & & & & $\begin{array}{c}0.157 \\
(0.105)\end{array}$ \\
\hline Constant & $\begin{array}{c}40.12 * * * \\
(4.793)\end{array}$ & $\begin{array}{c}48.81^{* * *} \\
(8.416)\end{array}$ & $\begin{array}{c}36.66 * * * \\
(6.370)\end{array}$ & $\begin{array}{c}44.20 * * * \\
(7.639)\end{array}$ & $\begin{array}{c}20.84 * * * \\
(6.308)\end{array}$ & $\begin{array}{l}19.74^{*} \\
(9.779)\end{array}$ \\
\hline Observations & 87 & 83 & 88 & 82 & 40 & 32 \\
\hline R-squared & 0.123 & 0.143 & 0.121 & 0.122 & 0.356 & 0.238 \\
\hline
\end{tabular}

In the next step, the empirical content of Hypothesis 2 is tested employing the fine and the broad classification of majority religions and the continuous population shares of major religions (Tables 7-9). Again, we also include sub-sample estimations across income classes (columns 2 and 3). For the fine classification (Table 7), the Orthodox Christian countries are chosen as the reference case. No significant differences can be detected for Roman Catholic countries whereas all other religions are associated with smaller shadow economies. The effects are less pronounced for Protestant and other Christian countries but particularly marked for the Islam, the Buddhist/Hindu and the "Other" category, which all have shadow economies that are nine to eleven percentage points of GDP smaller compared to the Orthodox reference case. These findings already point to Christian countries having a significantly larger shadow economy (for comparable levels of development and government effectiveness). This general tendency is reconfirmed both by the broader country classification (Table 8) and the test based on main religions' population shares (Table 9) where non-Christian religious orientation is always associated with a lower extent of informal transactions - even compared to countries with a larger non-religious population share. The sub-samples indicate that these overall findings originate largely from middle and low income countries; for industrialized countries religion dummies and population shares lose significance - with the exception of the Islam dummy in the fine classification.

Given the reflections on the religions' ethical messages above, the findings considering the sign of the Islam dummy and population share may come as a particular surprise since Islamic ethics apparently imply some objections at least to certain types of modern taxation. In spite of this, Islam countries do not have larger black economies compared to Christian countries of a similar stage of development. 
Table 7: Impact of majority religion (H2) - fine differences

\begin{tabular}{lccc}
\hline & $\begin{array}{c}(1) \\
\text { Total }\end{array}$ & $\begin{array}{c}(2) \\
\text { High income }\end{array}$ & $\begin{array}{c}(3) \\
\text { Middle/low } \\
\text { income }\end{array}$ \\
\hline GDP per capita & $-0.266^{* * *}$ & -0.076 & $-0.819^{* *}$ \\
Government effectiveness & $(0.094)$ & $(0.098)$ & $(0.374)$ \\
& $-6.668^{* * *}$ & $-6.018^{* * *}$ & $-4.189^{* *}$ \\
Catholic & $(1.276)$ & $(1.663)$ & $(2.038)$ \\
& -3.953 & -4.140 & -3.648 \\
Protestant & $(3.087)$ & $(4.020)$ & $(3.943)$ \\
& $-6.948^{*}$ & -5.191 & $-11.68^{* *}$ \\
Other Christian & $(3.709)$ & $(4.331)$ & $(5.537)$ \\
& $-5.901^{*}$ & -6.369 & -6.152 \\
Islam & $(3.243)$ & $(4.176)$ & $(4.268)$ \\
& $-9.412^{* * *}$ & $-8.411^{*}$ & $-11.40^{* * *}$ \\
Buddhist/Hindu & $(3.086)$ & $(4.728)$ & $(3.881)$ \\
& $-10.97^{* * *}$ & & $-14.27 * * *$ \\
Other & $(3.987)$ & & $(4.885)$ \\
& $-9.116^{* * *}$ & -7.249 & $-11.35^{* *}$ \\
Constant & $(3.391)$ & $(4.639)$ & $(4.342)$ \\
& $43.29^{* * *}$ & $35.62^{* * *}$ & $48.44 * * *$ \\
Observations & $(2.915)$ & $(4.039)$ & $(4.350)$ \\
R-squared & 148 & 46 & 101 \\
\hline Reference case majority religion dummies: Orthodox Christian, standard errors in parentheses, \\
$* * * \mathrm{p}<0.01, * * \mathrm{p}<0.05, * \mathrm{p}<0.1$ & &
\end{tabular}

Table 8: Impact of majority religion (H2) - broad differences

\begin{tabular}{lccc}
\hline & $(1)$ & $(2)$ & $(3)$ \\
& Total & High income & $\begin{array}{c}\text { Middle/low } \\
\text { income }\end{array}$ \\
\hline GDP per capita & $-0.251^{* * *}$ & -0.070 & -0.573 \\
Government effectiveness & $(0.094)$ & $(0.097)$ & $(0.355)$ \\
& $-7.127^{* * *}$ & $-6.350^{* * *}$ & $-4.984^{* *}$ \\
Islam & $(1.244)$ & $(1.571)$ & $(1.984)$ \\
& $-5.123^{* * *}$ & -4.026 & $-6.640^{* * *}$ \\
Other & $(1.814)$ & $(3.101)$ & $(2.271)$ \\
& $-5.320^{* * *}$ & -2.523 & $-7.545^{* * *}$ \\
Constant & $(1.929)$ & $(2.802)$ & $(2.510)$ \\
& $38.72^{* * *}$ & $31.15^{* * *}$ & $42.39 * * *$ \\
& $(1.323)$ & $(2.000)$ & $(2.538)$ \\
\hline Observations & 148 & 46 & 101 \\
R-squared & 0.559 & 0.510 & 0.225 \\
\hline Reference case majority religion dummies: Christian, standard errors in parentheses, \\
$* * * \mathrm{p}<0.01, * * \mathrm{p}<0.05, * \mathrm{p}<0.1$ & &
\end{tabular}


Table 9: Impact of majority religion (H2) - religious shares

\begin{tabular}{lccc}
\hline & $(1)$ & $(2)$ & $(3)$ \\
& Total & High income & $\begin{array}{c}\text { Middle/low } \\
\text { income }\end{array}$ \\
\hline GDP per capita & $-0.316^{* * *}$ & 0.009 & $-0.760^{*}$ \\
Government effectiveness & $(0.116)$ & $(0.145)$ & $(0.397)$ \\
Share Islam & $-6.148^{* * *}$ & $-7.061^{* * *}$ & $-4.295^{* *}$ \\
& $(1.447)$ & $(1.874)$ & $(2.094)$ \\
Share other religions & $-0.0651^{* * *}$ & -0.0614 & $-0.0840^{* * *}$ \\
Share no religion & $(0.0223)$ & $(0.0380)$ & $(0.0281)$ \\
Constant & $-0.0636^{* *}$ & -0.0387 & $-0.0996 * *$ \\
& $(0.0304)$ & $(0.0398)$ & $(0.0418)$ \\
& $-0.165^{* *}$ & -0.0355 & $-0.193^{* *}$ \\
Observations & $(0.0647)$ & $(0.0875)$ & $(0.0827)$ \\
R-squared & $40.24 * * *$ & $30.66 * * *$ & $44.52 * * *$ \\
\hline Reference case religious shares: Christian share, standard errors in parentheses, \\
$* * * \mathrm{p}<0.01, * * \mathrm{p}<0.05, *$ p $<0.1$
\end{tabular}

The regressions of Tables 10-12 account for different degrees of competition at the national markets for religion. The results which relate to Hypothesis 3 do not point to any strong impact: For none of the included three indicators (Herfindahl, population share of the majority religion and the state religion dummy) any significant effect emerges for the full sample or the middle and low income subsample. Only for high income countries, there is a significant positive sign for the Herfindahl index. Ceteris paribus, industrial countries with more intense religious competition have smaller shadow economies compared to less competitive countries. For industrial countries, this result supports the view that low religious competition reduces the power and normative influence of religious communities on their followers. However, the lacking robustness of this finding must be stressed. Even for the industrial countries, the effect of the Herfindahl index cannot be reproduced for the two alternative indicators of competition.

Table 10: Impact of religious competition (H3) - all countries

\begin{tabular}{lccc}
\hline & $(1)$ & $(2)$ & $(3)$ \\
\hline GDP per capita & -0.200 & $-0.280^{* * *}$ & $-0.263^{* * *}$ \\
& $(0.200)$ & $(0.095)$ & $(0.096)$ \\
Government effectiveness & $-7.795^{* * *}$ & $-6.172^{* * *}$ & $-6.249^{* * *}$ \\
& $(2.556)$ & $(1.234)$ & $(1.234)$ \\
Herfindahl index religious diversity & -2.204 & & \\
& $(4.749)$ & & \\
Population share majority religion & & 0.0171 & \\
& & $(0.0339)$ & -1.317 \\
Established religion & & & $(1.728)$ \\
& & & \\
Constant & $37.39 * * *$ & $35.62^{* * *}$ & $36.93^{* * *}$ \\
& $(3.238)$ & $(2.533)$ & $(1.255)$ \\
\hline Observations & 78 & 148 & 148 \\
R-squared & 0.546 & 0.522 & 0.523 \\
\hline Standard errors in parentheses, ${ }^{* * *} \mathrm{p}<0.01, * * \mathrm{p}<0.05, * \mathrm{p}<0$. & \\
& & & \\
& &
\end{tabular}


Table 11: Impact of religious competition (H3) - high income

\begin{tabular}{|c|c|c|c|}
\hline & $(1)$ & $(2)$ & (3) \\
\hline GDP per capita & $\begin{array}{c}-0.389 * * * \\
(0.124)\end{array}$ & $\begin{array}{c}-0.164^{* *} \\
(0.077)\end{array}$ & $\begin{array}{l}-0.152 * \\
(0.083)\end{array}$ \\
\hline Government effectiveness & $\begin{array}{l}-2.344 \\
(1.988)\end{array}$ & $\begin{array}{c}-4.826 * * * \\
(1.186)\end{array}$ & $\begin{array}{c}-4.971^{* * * *} \\
(1.236)\end{array}$ \\
\hline Herfindahl index religious diversity & $\begin{array}{l}7.273 * * \\
(3.371)\end{array}$ & & \\
\hline Population share majority religion & & $\begin{array}{c}0.0323 \\
(0.0334)\end{array}$ & \\
\hline Established religion & & & $\begin{array}{c}0.268 \\
(1.837)\end{array}$ \\
\hline Constant & $\begin{array}{c}29.15^{* * *} \\
(2.752)\end{array}$ & $\begin{array}{c}28.81^{* * * *} \\
(2.896)\end{array}$ & $\begin{array}{c}30.81 * * * \\
(2.022)\end{array}$ \\
\hline Observations & 37 & 46 & 46 \\
\hline R-squared & 0.628 & 0.494 & 0.483 \\
\hline
\end{tabular}

Table 12: Impact of religious competition (H3) - middle and low income

\begin{tabular}{lccc}
\hline & $(1)$ & $(2)$ & $(3)$ \\
\hline GDP per capita & -0.120 & -0.308 & -0.302 \\
& $(0.750)$ & $(0.370)$ & $(0.364)$ \\
Government effectiveness & $-9.800^{*}$ & $-5.476^{* *}$ & $-5.176^{* *}$ \\
& $(5.053)$ & $(2.097)$ & $(2.100)$ \\
Herfindahl index religious diversity & -8.517 & & \\
& $(9.001)$ & & \\
Population share majority religion & & 0.0036 & \\
& & $(0.0502)$ & -2.444 \\
Established religion & & & $(2.469)$ \\
& & & $38.28^{* * *}$ \\
Constant & $40.42^{* * *}$ & $37.40^{* * *}$ & $(2.378)$ \\
& $(6.367)$ & $(3.963)$ & 101 \\
Observations & 40 & 101 & 0.128 \\
R-squared & 0.161 & 0.120 & \\
\hline Standard errors in parentheses, ${ }^{* * *} \mathrm{p}<0.01, * * \mathrm{p}<0.05, * \mathrm{p}<0.1$ & \\
& & & \\
& &
\end{tabular}

Our further set of regressions focuses on the links between a country's dominant religion and the secular authorities (Hypothesis 4). Actually, the overall RAS indicator, which combines numerous dimensions in the relation between religion and the state, is significant for the overall sample with the expected sign (Table 13): A larger proximity between religious and state organizations is associated with a smaller shadow economy. This general finding is reiterated for some of the sub-dimensions: For countries where laws have at least partially a foundation in religious doctrines, where the government tends to discriminate against other religions to the advantage of the government's religious partner or where religious education is mandatory in public schools. A look at the subsamples reveals specific differences (Tables 14-15): The effects of proximity are limited to middle and low income countries whereas no significances can be observed in the sample with industrial countries. We also include regressions limited to the dominantly Christian (Table 16) and Islamic (Table 17) countries. Interestingly, for Christian countries the significant coefficients have an opposite sign with strong ties between religion and the state being rather typical for countries with larger shadow economies. The 
Islamic countries, by contrast, confirm the overall result with even higher negative coefficients.

Table 13: Impact of ties between state and religion (H4) - all countries

\begin{tabular}{|c|c|c|c|c|c|c|}
\hline & $(1)$ & $(2)$ & (3) & (4) & (5) & (6) \\
\hline GDP per capita & $\begin{array}{c}-0.238 * * \\
(0.094)\end{array}$ & $\begin{array}{c}-0.235^{* *} \\
(0.095)\end{array}$ & $\begin{array}{c}-0.227 * * \\
(0.095)\end{array}$ & $\begin{array}{l}-0.222 * * \\
(0.0961)\end{array}$ & $\begin{array}{c}-0.276 * * * \\
(0.0949)\end{array}$ & $\begin{array}{c}-0.278 * * * \\
(0.0960)\end{array}$ \\
\hline Government effectiveness & $\begin{array}{c}-6.658 * * * \\
(1.223)\end{array}$ & $\begin{array}{c}-6.732 * * * \\
(1.229)\end{array}$ & $\begin{array}{c}-6.840 * * * \\
(1.234)\end{array}$ & $\begin{array}{c}-6.806 * * * \\
(1.241)\end{array}$ & $\begin{array}{c}-6.067 * * * \\
(1.276)\end{array}$ & $\begin{array}{c}-6.197 * * * \\
(1.235)\end{array}$ \\
\hline Index religion and state & $\begin{array}{l}-0.110^{* *} \\
(0.0439)\end{array}$ & & & & & \\
\hline Religious laws & & $\begin{array}{c}-4.527 * * \\
(1.846)\end{array}$ & & & & \\
\hline Discrimination minority relig. & & & $\begin{array}{c}-0.264 * * \\
(0.103)\end{array}$ & & & \\
\hline Mandatory relig. education & & & & $\begin{array}{c}-4.512 * * \\
(1.955)\end{array}$ & & \\
\hline Religious taxes & & & & & $\begin{array}{l}-0.972 \\
(2.557)\end{array}$ & \\
\hline Government pays clergy & & & & & & $\begin{array}{c}0.258 \\
(1.719)\end{array}$ \\
\hline Constant & $\begin{array}{c}38.89 * * * \\
(1.482) \\
\end{array}$ & $\begin{array}{c}37.21^{* * *} \\
(1.221)\end{array}$ & $\begin{array}{c}37.57 * * * \\
(1.247)\end{array}$ & $\begin{array}{c}36.97 * * * \\
(1.212)\end{array}$ & $\begin{array}{c}36.84^{* * * *} \\
(1.259)\end{array}$ & $\begin{array}{c}36.69 * * * \\
(1.268)\end{array}$ \\
\hline Observations & 148 & 148 & 148 & 148 & 148 & 148 \\
\hline R-squared & 0.541 & 0.540 & 0.542 & 0.538 & 0.522 & 0.521 \\
\hline
\end{tabular}

Table 14: Impact of ties between state and religion (H4) - high income

\begin{tabular}{|c|c|c|c|c|c|c|}
\hline & (1) & (2) & (3) & (4) & (5) & (6) \\
\hline GDP per capita & -0.118 & -0.128 & -0.092 & $\begin{array}{c}-0.139 \\
(0.0968)\end{array}$ & -0.136* & ${ }^{-0.147 *}$ \\
\hline Government effectiveness & $\begin{array}{c}-5.590 * * * \\
(1.373)\end{array}$ & $\begin{array}{c}-5.431 * * * \\
(1.469)\end{array}$ & $\begin{array}{c}-5.928 * * * \\
(1.405)\end{array}$ & $\begin{array}{c}-5.185 * * * \\
(1.567)\end{array}$ & $\begin{array}{c}-5.311^{* * *} \\
(1.218)\end{array}$ & $\begin{array}{c}-5.031 * * * \\
(1.186)\end{array}$ \\
\hline Index religion and state & $\begin{array}{l}-0.0455 \\
(0.0575)\end{array}$ & & & & & \\
\hline Religious laws & & $\begin{array}{l}-1.169 \\
(2.526)\end{array}$ & & & & \\
\hline Discrimination minority relig. & & & $\begin{array}{l}-0.156 \\
(0.136)\end{array}$ & & & \\
\hline Mandatory relig. education & & & & $\begin{array}{c}-0.432 \\
(2.768)\end{array}$ & & \\
\hline Religious taxes & & & & & $\begin{array}{c}1.555 \\
(1.817)\end{array}$ & \\
\hline Government pays clergy & & & & & & $\begin{array}{c}-0.0932 \\
(1.614)\end{array}$ \\
\hline Constant & $\begin{array}{c}31.77 * * * \\
(2.318)\end{array}$ & $\begin{array}{c}31.02 * * * \\
(2.045)\end{array}$ & $\begin{array}{c}31.12 * * * \\
(1.997)\end{array}$ & $\begin{array}{c}30.86 * * * \\
(2.020) \\
\end{array}$ & $\begin{array}{c}30.41^{* * *} \\
(2.055)\end{array}$ & $\begin{array}{c}30.87 * * * \\
(2.076)\end{array}$ \\
\hline Observations & 46 & 46 & 46 & 46 & 46 & 46 \\
\hline R-squared & 0.491 & 0.486 & 0.499 & 0.483 & 0.492 & 0.483 \\
\hline
\end{tabular}


Table 15: Impact of ties between state and religion (H4) - middle and low income

\begin{tabular}{|c|c|c|c|c|c|c|}
\hline & $(1)$ & $(2)$ & (3) & (4) & (5) & $(6)$ \\
\hline GDP per capita & $\begin{array}{c}-0.225 \\
(0.356)\end{array}$ & $\begin{array}{c}-0.324 \\
(0.355)\end{array}$ & $\begin{array}{c}-0.284 \\
(0.354)\end{array}$ & $\begin{array}{c}-0.321 \\
(0.355)\end{array}$ & $\begin{array}{c}-0.303 \\
(0.364)\end{array}$ & $\begin{array}{c}-0.321 \\
(0.369)\end{array}$ \\
\hline Government effectiveness & $\begin{array}{c}-5.051 * * \\
(2.034)\end{array}$ & $\begin{array}{c}-4.951^{* *} \\
(2.039)\end{array}$ & $\begin{array}{c}-5.093 * * \\
(2.031)\end{array}$ & $\begin{array}{c}-4.887 * * \\
(2.041)\end{array}$ & $\begin{array}{c}-5.322^{* *} \\
(2.087)\end{array}$ & $\begin{array}{c}-5.523 * * * \\
(2.096)\end{array}$ \\
\hline Index religion and state & $\begin{array}{l}-0.148 * * \\
(0.0596)\end{array}$ & & & & & \\
\hline Religious laws & & $\begin{array}{c}-6.067 * * \\
(2.475)\end{array}$ & & & & \\
\hline Discrimination minority relig. & & & $\begin{array}{c}-0.349 * * \\
(0.139)\end{array}$ & & & \\
\hline Mandatory relig. education & & & & $\begin{array}{c}-6.526^{* *} \\
(2.639)\end{array}$ & & \\
\hline Religious taxes & & & & & $\begin{array}{l}-5.499 \\
(5.947)\end{array}$ & \\
\hline Government pays clergy & & & & & & $\begin{array}{c}0.897 \\
(2.597)\end{array}$ \\
\hline Constant & $\begin{array}{c}40.96 * * * \\
(2.601)\end{array}$ & $\begin{array}{c}39.14 * * * \\
(2.312)\end{array}$ & $\begin{array}{c}39.54 * * * \\
(2.352) \\
\end{array}$ & $\begin{array}{c}39.05^{* * * *} \\
(2.300)\end{array}$ & $\begin{array}{c}37.86 * * * \\
(2.300) \\
\end{array}$ & $\begin{array}{c}37.50^{* * * *} \\
(2.328) \\
\end{array}$ \\
\hline Observations & 101 & 101 & 101 & 101 & 101 & 101 \\
\hline R-squared & 0.172 & 0.171 & 0.173 & 0.172 & 0.127 & 0.121 \\
\hline
\end{tabular}

Table 16: Impact of ties between state and religion (H4) - Christian majority religion

\begin{tabular}{|c|c|c|c|c|c|c|}
\hline & $(1)$ & $(2)$ & (3) & $(4)$ & (5) & (6) \\
\hline GDP per capita & $\begin{array}{c}-0.340 * * \\
(0.144)\end{array}$ & $\begin{array}{c}-0.329 * * \\
(0.146)\end{array}$ & $\begin{array}{c}-0.345^{* *} \\
(0.143)\end{array}$ & $\begin{array}{c}-0.324 * * \\
(0.147)\end{array}$ & $\begin{array}{c}-0.341^{* *} \\
(0.146)\end{array}$ & $\begin{array}{c}-0.372^{* *} \\
(0.147)\end{array}$ \\
\hline Government effectiveness & $\begin{array}{c}-6.928 * * * \\
(1.674)\end{array}$ & $\begin{array}{c}-7.082 * * * \\
(1.697)\end{array}$ & $\begin{array}{c}-6.737 * * * \\
(1.668)\end{array}$ & $\begin{array}{c}-7.108 * * * \\
(1.709)\end{array}$ & $\begin{array}{c}-7.225^{* * *} \\
(1.747)\end{array}$ & $\begin{array}{c}-6.978 * * * \\
(1.684)\end{array}$ \\
\hline Index religion and state & $\begin{array}{c}0.136^{*} \\
(0.0812)\end{array}$ & & & & & \\
\hline Religious laws & & $\begin{array}{c}4.405 \\
(4.626)\end{array}$ & & & & \\
\hline Discrimination minority relig. & & & $\begin{array}{l}0.418^{*} \\
(0.215)\end{array}$ & & & \\
\hline Mandatory relig. education & & & & $\begin{array}{c}-2.544 \\
(3.667)\end{array}$ & & \\
\hline Religious taxes & & & & & $\begin{array}{c}1.763 \\
(2.799)\end{array}$ & \\
\hline Government pays clergy & & & & & & $\begin{array}{c}2.731 \\
(2.063)\end{array}$ \\
\hline Constant & $\begin{array}{c}37.43^{* * * *} \\
(2.198) \\
\end{array}$ & $\begin{array}{c}39.57 * * * \\
(1.706) \\
\end{array}$ & $\begin{array}{c}38.71 * * * \\
(1.753) \\
\end{array}$ & $\begin{array}{c}39.82 * * * \\
(1.690) \\
\end{array}$ & $\begin{array}{c}39.67 * * * \\
(1.707) \\
\end{array}$ & $\begin{array}{c}39.55 * * * \\
(1.690) \\
\end{array}$ \\
\hline Observations & 86 & 86 & 86 & 86 & 86 & 86 \\
\hline R-squared & 0.699 & 0.692 & 0.702 & 0.690 & 0.690 & 0.695 \\
\hline
\end{tabular}


Table 17: Impact of ties between state and religion (H4) - Islam majority religion

\begin{tabular}{|c|c|c|c|c|c|c|}
\hline & $(1)$ & $(2)$ & (3) & (4) & (5) & (6) \\
\hline GDP per capita & $\begin{array}{l}-0.177 \\
(0.118)\end{array}$ & $\begin{array}{c}-0.163 \\
(0.114)\end{array}$ & $\begin{array}{l}-0.169 \\
(0.134)\end{array}$ & $\begin{array}{l}-0.165 \\
(0.119)\end{array}$ & $\begin{array}{c}-0.243^{*} \\
(0.136)\end{array}$ & $\begin{array}{c}-0.194 \\
(0.132)\end{array}$ \\
\hline Government effectiveness & $\begin{array}{c}-1.397 \\
(2.879)\end{array}$ & $\begin{array}{c}-1.913 \\
(2.711)\end{array}$ & $\begin{array}{c}-3.533 \\
(3.087)\end{array}$ & $\begin{array}{l}-1.956 \\
(2.845)\end{array}$ & $\begin{array}{c}-4.072 \\
(3.193)\end{array}$ & $\begin{array}{c}-3.473 \\
(3.116)\end{array}$ \\
\hline Index religion and state & $\begin{array}{c}-0.262 * * * \\
(0.0757)\end{array}$ & & & & & \\
\hline Religious laws & & $\begin{array}{c}-12.04 * * * \\
(3.060)\end{array}$ & & & & \\
\hline Discrimination minority relig. & & & $\begin{array}{c}-0.324 * \\
(0.169)\end{array}$ & & & \\
\hline Mandatory relig. education & & & & $\begin{array}{c}-10.29 * * * \\
(3.013)\end{array}$ & & \\
\hline Religious taxes & & & & & $\begin{array}{l}-5.159 \\
(4.921)\end{array}$ & \\
\hline Government pays clergy & & & & & & $\begin{array}{l}-5.934 * \\
(3.282)\end{array}$ \\
\hline Constant & $\begin{array}{c}44.81^{* * *} \\
(3.817)\end{array}$ & $\begin{array}{c}42.56 * * * \\
(3.045)\end{array}$ & $\begin{array}{c}37.34^{* * *} \\
(3.014)\end{array}$ & $\begin{array}{c}39.60 * * * \\
(2.768) \\
\end{array}$ & $\begin{array}{c}35.04 * * * \\
(2.743) \\
\end{array}$ & $\begin{array}{c}36.51 * * * \\
(2.842) \\
\end{array}$ \\
\hline Observations & 35 & 35 & 35 & 35 & 35 & 35 \\
\hline R-squared & 0.488 & 0.527 & 0.365 & 0.484 & 0.315 & 0.358 \\
\hline
\end{tabular}

Finally, we combine key indicators for the four hypotheses in a synthesis regression (Tables 18). This comprehensive estimation stresses the robustness of the H2 support: As shown before (Tables 7-9), Christian countries have larger shadow economies compared to countries where Islam or other religions dominate. Again, this finding for the total country sample is largely driven by the strength of the link for middle and low income sub-sample. The H4 related index for the proximity between religion and state misses significance in our comprehensive regression. Statistically, this is a consequence of a significant correlation between this index and the religion dummy: Islamic (Christian) countries have more (less) often close ties between the religious and the secular authorities. ${ }^{9}$ Therefore, we explore the link between both religious indicators through an interaction as well (Table 19). Indeed, the interactions between the religion dummies and the index on religion and state are significant, a finding which establishes the interplay of $\mathrm{H} 2$ and $\mathrm{H} 4$. The proximity between religion and state matters and tends to reduce the size of the shadow economy in middle and low income countries. However, this rather holds for the Islam and other non-Christian religions. These details also help to understand the puzzle that Islam in spite of its comparatively lenient tax ethics is associated with smaller shadow economies. Our results point out that it is rather the closeness between the Islam and the secular government which is responsible than the ethical teaching of Islam as such. Typically, secular and religious authorities have closer ties in Islamic countries and this proximity has a stronger effect on the shadow economy compared to Christian countries.

\footnotetext{
${ }^{9}$ The correlation coefficients are +0.53 for the Islam dummy and the aggregate index on religion and state. The correlation is -0.43 for the Christianity dummy and the index.
} 
Table 18: Synthesis regression

\begin{tabular}{lccc}
\hline & $(1)$ & $(2)$ & $(3)$ \\
& Total & High income & Middle/low income \\
\hline GDP per capita & $-0.281^{* *}$ & -0.133 & $-1.053^{*}$ \\
& $(0.108)$ & $(0.138)$ & $(0.539)$ \\
Government effectiveness & $-6.918^{* * *}$ & $-6.828^{* *}$ & -3.159 \\
& $(1.583)$ & $(2.547)$ & $(2.583)$ \\
Religiosity Index (H1) & 0.0437 & 0.0383 & -0.0528 \\
(Gallup) & $(0.0541)$ & $(0.0672)$ & $(0.0825)$ \\
Islam (H2) & $-5.455^{* *}$ & -5.971 & $-6.323^{* *}$ \\
& $(2.507)$ & $(7.836)$ & $(3.080)$ \\
Other (H2) & $-5.234^{* *}$ & -1.774 & $-8.138^{* *}$ \\
& $(2.280)$ & $(2.874)$ & $(3.172)$ \\
Population share majority religion (H3) & 0.0333 & 0.0364 & 0.0150 \\
& $(0.0409)$ & $(0.0455)$ & $(0.0622)$ \\
Index religion and state (H4) & -0.0836 & -0.0246 & -0.106 \\
& $(0.0625)$ & $(0.103)$ & $(0.0850)$ \\
Constant & $36.38 * * *$ & $29.72 * * *$ & $50.93^{* * *}$ \\
& $(4.426)$ & $(4.341)$ & $(8.497)$ \\
\hline Observations & 122 & 40 & 81 \\
R-squared & 0.611 & 0.582 & 0.266 \\
\hline Reference case majority religion dummies: Christian, standard errors in parentheses, *** $\mathrm{p}<0.01, * * \mathrm{p}<0.05, * \mathrm{p}<0.1$
\end{tabular}

Table 19: Synthesis regression including interaction $\mathrm{H} 2 / \mathrm{H} 4$

\begin{tabular}{lccc}
\hline & $(1)$ & $(2)$ & $(3)$ \\
& Total & High income & Middle/low income \\
\hline GDP per capita & $-0.243^{* *}$ & -0.198 & $-0.937^{*}$ \\
& $(0.106)$ & $(0.143)$ & $(0.539)$ \\
Government effectiveness & $-6.623^{* * *}$ & $-6.327^{* *}$ & -2.641 \\
& $(1.538)$ & $(2.542)$ & $(2.503)$ \\
Religiosity Index (H1) & 0.0814 & 0.0236 & -0.00519 \\
(Gallup) & $(0.0540)$ & $(0.0689)$ & $(0.0846)$ \\
Islam (H2) & 4.433 & 16.71 & 3.849 \\
& $(4.264)$ & $(15.88)$ & $(5.413)$ \\
Other (H2) & 0.595 & -2.705 & 0.945 \\
& $(3.805)$ & $(4.614)$ & $(5.373)$ \\
Population share majority religion (H3) & 0.00630 & 0.0499 & -0.00435 \\
& $(0.0407)$ & $(0.0478)$ & $(0.0605)$ \\
Index religion and state (H4) & 0.170 & -0.0165 & 0.204 \\
& $(0.103)$ & $(0.124)$ & $(0.142)$ \\
Islam x index religion and state & $-0.394^{* * *}$ & -0.364 & $-0.436^{* *}$ \\
& $(0.132)$ & $(0.234)$ & $(0.179)$ \\
Other x index religion and state & $-0.329^{* *}$ & 0.0643 & $-0.473^{* *}$ \\
& $(0.166)$ & $(0.205)$ & $(0.226)$ \\
Constant & $30.84^{* * *}$ & $30.24 * * *$ & $42.92^{* * *}$ \\
& $(4.670)$ & $(4.540)$ & $(9.081)$ \\
\hline Observations & 122 & 40 & 81 \\
R-squared & 0.641 & 0.617 & 0.335 \\
\hline Reference case majority religion dummies: Christian, standard errors in parentheses, *** $\mathrm{p}<0.01, * * \mathrm{p}<0.05, * \mathrm{p}<0.1$
\end{tabular}




\subsection{Further robustness checks}

The preceding testing has supported two of the four presented hypotheses: There are actually significant differences in the size of the shadow economy, which correspond to dominant religions (H2); and the links between the religion and the state matter with the expected sign closer links are apparently helpful to constrain informal transactions (H4).

Critical reflections are necessary for cross-country results like these. Reversed causation issues are less of a concern for religious indicators because a country's religious characteristics date back long in history and in most cases far before the development of the modern fiscal state. For example, we can exclude that the size of the shadow economy has an impact on a country's dominant religion. A similar confidence is justified for the proximity between religion and the state, which is also deeply rooted in a country's history. A more serious threat, however, is that results are just an accidental outcome of a particular specification and do not survive slight variations of the estimation specification or the coverage of observations.

Therefore, we report and present robustness checks with respect to our essential findings. We include some of the central total sample regressions: With respect to $\mathrm{H} 2$, we thus subject the results of the broad country classification for majority religion dummies and the population share specification (Tables 8 and 9) to a robustness test. Furthermore, with respect to H4, the results for the overall RAS indicator and the significant sub-indicators (Table 13) are subject to a robustness test as well.

For a first robustness check, we deal with the problem of outliers and thus the robustness with respect to the inclusion or weighting of observations (Table 20). We apply the M-estimator, which downweights the influence of outliers. The negative impact of Islam remains significant (5 per cent) both for the dummy and the population share. The results for the indicators on religion and state, both for the aggregate and the sub-indicators, remain the same with respect to significance levels and magnitudes. 
Table 20: Robustness checks - outliers

\begin{tabular}{|c|c|c|c|c|c|c|}
\hline & $(1)$ & $(1)$ & (3) & $(4)$ & (5) & $(6)$ \\
\hline GDP per capita & $\begin{array}{c}-0.323 * * * \\
(0.107)\end{array}$ & $\begin{array}{c}-0.242 * * * \\
(0.086)\end{array}$ & $\begin{array}{c}-0.236 * * * \\
(0.084)\end{array}$ & $\begin{array}{c}-0.241 * * * \\
(0.084)\end{array}$ & $\begin{array}{c}-0.212 * * \\
(0.084)\end{array}$ & $\begin{array}{c}-0.229 * * * \\
(0.0853)\end{array}$ \\
\hline Government effectiveness & $\begin{array}{c}-6.154 * * * \\
(1.333)\end{array}$ & $\begin{array}{c}-6.898 * * * \\
(1.143)\end{array}$ & $\begin{array}{c}-6.423 * * * \\
(1.088)\end{array}$ & $\begin{array}{c}-6.511 * * * \\
(1.088)\end{array}$ & $\begin{array}{c}-6.792 * * * \\
(1.096)\end{array}$ & $\begin{array}{c}-6.574 * * * \\
(1.102)\end{array}$ \\
\hline Share Islam & $\begin{array}{c}-0.052 * * \\
(0.021)\end{array}$ & & & & & \\
\hline Share other religion & $\begin{array}{c}-0.045 \\
(0.028)\end{array}$ & & & & & \\
\hline Share no religion & $\begin{array}{l}-0.085 \\
(0.060)\end{array}$ & & & & & \\
\hline Islam & & $\begin{array}{c}-3.618 * * \\
(1.666)\end{array}$ & & & & \\
\hline Other religion & & $\begin{array}{c}-3.368^{*} \\
(1.772)\end{array}$ & & & & \\
\hline Index religion and state & & & $\begin{array}{c}-0.0981 * * \\
(0.0391)\end{array}$ & & & \\
\hline Religious laws & & & & $\begin{array}{c}-3.935 * * \\
(1.633)\end{array}$ & & \\
\hline Discrimination minority relig. & & & & & $\begin{array}{c}-0.303^{* * *} \\
(0.0917)\end{array}$ & \\
\hline Mandatory relig. education & & & & & & $\begin{array}{c}-3.824^{* *} \\
(1.736)\end{array}$ \\
\hline Constant & $\begin{array}{c}38.89 * * * \\
(1.530)\end{array}$ & $\begin{array}{c}37.49 * * * \\
(1.215) \\
\end{array}$ & $\begin{array}{c}38.03 * * * \\
(1.318)\end{array}$ & $\begin{array}{c}36.75^{* * *} \\
(1.080) \\
\end{array}$ & $\begin{array}{c}36.96 * * * \\
(1.108) \\
\end{array}$ & $\begin{array}{c}36.43 * * * \\
(1.077) \\
\end{array}$ \\
\hline Observations & 133 & 148 & 148 & 148 & 148 & 148 \\
\hline R-squared & 0.596 & 0.585 & 0.584 & 0.591 & 0.591 & 0.587 \\
\hline
\end{tabular}

Subsequently (Table 21), we test for the robustness of our findings against variations of the baseline specification. For that purpose, we augment the baseline controls (GDP per capita and government effectiveness) by the five further possible control variables (size of government, unemployment rate, business freedom, fiscal freedom and freedom from corruption) and combine the religious indicator under scrutiny with all possible permutations of these core regression variables. The share of significant cases then gives an indication of the reliability of the significance. It turns out that significances are no accidental outcome of a particular specification of the economic drivers of the shadow economy. The shares of significant coefficients for the religious indicators lay in the range between 80 and 100 percent. The overall religion and state indicator reaches a share of 95 percent of significant results for all permutations of economic controls. 
Table 21: Robustness checks - baseline variations

\begin{tabular}{|c|c|c|c|c|c|c|c|c|}
\hline & Max & Min & Mean & $\begin{array}{l}\text { Significant } \\
\text { cases }\end{array}$ & $>0$ & $<0$ & $\begin{array}{l}\text { Avg. } \\
\text { t-statistic }\end{array}$ & Obs. \\
\hline \multicolumn{9}{|c|}{ H2: majority religion dummies } \\
\hline Islam & 0.54 & -7.66 & -5.18 & $81 \%$ & $2 \%$ & $98 \%$ & 2.63 & 128 \\
\hline Other & -0.60 & -6.62 & -5.57 & $91 \%$ & $0 \%$ & $100 \%$ & 2.60 & 128 \\
\hline \multicolumn{9}{|c|}{ H2: population shares religions } \\
\hline Islam & 0.00 & -0.09 & -0.07 & $88 \%$ & $2 \%$ & $98 \%$ & 2.78 & 128 \\
\hline Other & -0.01 & -0.09 & -0.07 & $84 \%$ & $0 \%$ & $100 \%$ & 2.08 & 128 \\
\hline None & -0.13 & -0.40 & -0.28 & $100 \%$ & $0 \%$ & $100 \%$ & 3.06 & 128 \\
\hline \multicolumn{9}{|c|}{ H4: Index religion and state } \\
\hline Index & -0.07 & -0.18 & -0.13 & $95 \%$ & $0 \%$ & $100 \%$ & 2.65 & 128 \\
\hline \multicolumn{9}{|c|}{ H4: religious education } \\
\hline Dummy & -2.12 & -7.31 & -5.02 & $76 \%$ & $0 \%$ & $100 \%$ & 2.29 & 128 \\
\hline \multicolumn{9}{|c|}{ H4: discrimination of minority religions } \\
\hline Dummy & -0.15 & -0.48 & -0.33 & $94 \%$ & $0 \%$ & $100 \%$ & 2.78 & 128 \\
\hline \multicolumn{9}{|c|}{ H4: religious laws } \\
\hline Dummy & -2.71 & -7.25 & -5.36 & $87 \%$ & $0 \%$ & $100 \%$ & 2.55 & 128 \\
\hline $\begin{array}{l}\text { “Signific } \\
\text { through } \\
\text { ploymen }\end{array}$ & $\begin{array}{l}\text { nt cases } \\
\text { ll comb } \\
\text { rate, bus }\end{array}$ & $\begin{array}{l}\text { reports } \\
\text { nations } \\
\text { iness fre }\end{array}$ & $\begin{array}{l}\text { the shar } \\
\text { of the bi } \\
\text { eedom, fi }\end{array}$ & $\begin{array}{l}\text { where coef } \\
\text { seline varial } \\
\text { scal freedom }\end{array}$ & $\begin{array}{l}\text { cients } \\
\text { es: G } \\
\text { and fre }\end{array}$ & $\begin{array}{l}\text { in quest } \\
\text { DP per } \\
\text { edom fr }\end{array}$ & $\begin{array}{l}\text { ons have a } \\
\text { mita, gove } \\
\text { m corrupti }\end{array}$ & $\begin{array}{l}\text { least } 10 \% \text { significance; } 128 \text { regressions achieved } \\
\text { nment effectiveness, size of government, unem- } \\
\text { n. }\end{array}$ \\
\hline \multicolumn{9}{|c|}{ Finally, we perform a test with respect to a possible non-standard distribution of error terms: } \\
\hline \multirow{3}{*}{\multicolumn{9}{|c|}{$\begin{array}{l}\text { Robust Huber-White standard errors (Table 22) leave our findings unaffected. Clustering the } \\
\text { error terms at the level of the fine religious country classification strongly reconfirms the sig- } \\
\text { nificant differences across religions (Table 23). The significance level for the RAS indicators }\end{array}$}} \\
\hline & & & & & & & & \\
\hline & & & & & & & & \\
\hline drop w & h the & cluste & ring, b & ut the $\mathrm{RA}$ & S ov & rall is & licator a & ad the discrimination dummy remain \\
\hline
\end{tabular}


Table 22: Robustness checks - non-standard error terms

\begin{tabular}{|c|c|c|c|c|c|c|}
\hline & $(1)$ & $(1)$ & (3) & $(4)$ & (5) & $(6)$ \\
\hline GDP per capita & $\begin{array}{c}-0.316^{* *} \\
(0.138)\end{array}$ & $\begin{array}{c}-0.251^{* * *} \\
(0.0845)\end{array}$ & $\begin{array}{c}-0.238 * * * \\
(0.0845)\end{array}$ & $\begin{array}{c}-0.235^{* * *} \\
(0.0847)\end{array}$ & $\begin{array}{l}-0.227 * * \\
(0.0890)\end{array}$ & $\begin{array}{l}-0.222 * * \\
(0.0855)\end{array}$ \\
\hline Government effectiveness & $\begin{array}{c}-6.148^{* * *} \\
(1.481)\end{array}$ & $\begin{array}{c}-7.127 * * * \\
(1.043)\end{array}$ & $\begin{array}{c}-6.658 * * * \\
(0.968)\end{array}$ & $\begin{array}{c}-6.732 * * * \\
(0.975)\end{array}$ & $\begin{array}{c}-6.840 * * * \\
(1.027)\end{array}$ & $\begin{array}{c}-6.806 * * * \\
(0.974)\end{array}$ \\
\hline Share Islam & $\begin{array}{c}-0.0651^{* * * *} \\
(0.0240)\end{array}$ & & & & & \\
\hline Share other religion & $\begin{array}{c}-0.0636 * \\
(0.0373)\end{array}$ & & & & & \\
\hline Share no religion & $\begin{array}{c}-0.165 * * \\
(0.0824)\end{array}$ & & & & & \\
\hline Islam & & $\begin{array}{c}-5.123^{* * *} \\
(1.878)\end{array}$ & & & & \\
\hline Other religion & & $\begin{array}{c}-5.320 * * \\
(2.143)\end{array}$ & & & & \\
\hline Index religion and state & & & $\begin{array}{c}-0.110^{* *} \\
(0.0455)\end{array}$ & & & \\
\hline Religious laws & & & & $\begin{array}{c}-4.527 * * \\
(1.922)\end{array}$ & & \\
\hline Discrimination minority relig. & & & & & $\begin{array}{c}-0.264 * * \\
(0.127)\end{array}$ & \\
\hline Mandatory relig. education & & & & & & $\begin{array}{c}-4.512 * * \\
(2.178)\end{array}$ \\
\hline Constant & $\begin{array}{c}40.24 * * * \\
(1.898) \\
\end{array}$ & $\begin{array}{c}38.72 * * * \\
(1.309) \\
\end{array}$ & $\begin{array}{c}38.89 * * * \\
(1.370) \\
\end{array}$ & $\begin{array}{c}37.21 * * * \\
(1.272)\end{array}$ & $\begin{array}{c}37.57 * * * \\
(1.193) \\
\end{array}$ & $\begin{array}{c}36.97 * * * \\
(1.246)\end{array}$ \\
\hline Observations & 133 & 148 & 148 & 148 & 148 & 148 \\
\hline R-squared & 0.564 & 0.559 & 0.541 & 0.540 & 0.542 & 0.538 \\
\hline
\end{tabular}

Table 23: Robustness checks - clustered errors

\begin{tabular}{|c|c|c|c|c|c|c|}
\hline & $(1)$ & $(1)$ & (3) & (4) & $(5)$ & $(6)$ \\
\hline GDP per capita & $\begin{array}{c}-0.316 * * \\
(0.0916)\end{array}$ & $\begin{array}{c}-0.251^{* * *} \\
(0.0494)\end{array}$ & $\begin{array}{c}-0.238 * * \\
(0.0723)\end{array}$ & $\begin{array}{c}-0.235^{* *} \\
(0.0737)\end{array}$ & $\begin{array}{c}-0.227 * * \\
(0.0673)\end{array}$ & $\begin{array}{c}-0.222 * * \\
(0.0636)\end{array}$ \\
\hline Government effectiveness & $\begin{array}{c}-6.148 * * * \\
(0.785)\end{array}$ & $\begin{array}{c}-7.127 * * * \\
(0.411)\end{array}$ & $\begin{array}{c}-6.658 * * * \\
(0.508)\end{array}$ & $\begin{array}{c}-6.732 * * * \\
(0.488)\end{array}$ & $\begin{array}{c}-6.840 * * * \\
(0.329)\end{array}$ & $\begin{array}{c}-6.806 * * * \\
(0.629)\end{array}$ \\
\hline Share Islam & $\begin{array}{c}-0.0651 * * * \\
(0.0132)\end{array}$ & & & & & \\
\hline Share other religion & $\begin{array}{c}-0.0636^{* *} \\
(0.0173)\end{array}$ & & & & & \\
\hline Share no religion & $\begin{array}{c}-0.165 * * \\
(0.0490)\end{array}$ & & & & & \\
\hline Islam & & $\begin{array}{c}-5.123 * * * \\
(1.031)\end{array}$ & & & & \\
\hline Other religion & & $\begin{array}{c}-5.320 * * * \\
(1.212)\end{array}$ & & & & \\
\hline Index religion and state & & & $\begin{array}{c}-0.110^{*} \\
(0.0469)\end{array}$ & & & \\
\hline Religious laws & & & & $\begin{array}{l}-4.527 \\
(2.628)\end{array}$ & & \\
\hline Discrimination minority relig. & & & & & $\begin{array}{l}-0.264 * \\
(0.129)\end{array}$ & \\
\hline Mandatory relig. education & & & & & & $\begin{array}{l}-4.512 \\
(3.297)\end{array}$ \\
\hline Constant & $\begin{array}{c}40.24 * * * \\
(1.457)\end{array}$ & $\begin{array}{c}38.72 * * * \\
(1.182)\end{array}$ & $\begin{array}{c}38.89 * * * \\
(1.275)\end{array}$ & $\begin{array}{c}37.21^{* * *} \\
(1.434)\end{array}$ & $\begin{array}{c}37.57 * * * \\
(1.394)\end{array}$ & $\begin{array}{c}36.97 * * * \\
(1.476)\end{array}$ \\
\hline Observations & 133 & 148 & 148 & 148 & 148 & 148 \\
\hline R-squared & 0.564 & 0.559 & 0.541 & 0.540 & 0.542 & 0.538 \\
\hline
\end{tabular}

Clustering of standard errors at the country group level at fine religious classification (see Table 2),

$* * * \mathrm{p}<0.01, * * \mathrm{p}<0.05, * \mathrm{p}<0.1$ 


\section{Conclusions}

The latest research on the shadow economy and its interaction with the official economy (Feld and Schneider, 2010) shows that the shadow economy is not only influenced by "hard" factors such as tax pressure or regulation intensity. In addition, soft factors like tax moral play a role. Given that religions are important suppliers of ethical norms, the analysis of religion's possible impact on the shadow economy promises a better understanding of international variance.

Overall, our findings support the view that religion influences the level of informal transactions, albeit with several qualifications. It does not seem to be the case that the degree of individual general religiosity is crucial. The analysis did not support the view that countries with religious citizens have smaller shadow economies per se. However, there is significant divergence across main religions: Countries dominated by Islam or Eastern religions are associated with smaller shadow economies compared to Christian countries for comparable levels of economic development and government effectiveness. Furthermore, the proximity between state and religion is relevant whereas the degree of religious competition has no robust impact. Close ties between the dominant religion and the state, e.g. through legislation based on religious doctrines, are typical for countries with a lower share of economic activity in the informal sector. This is in line with the view that religion uses its normative influence as a "supernatural police" to protect state interests if there is a reciprocal relationship between religion and state. The relatively low shares of the shadow economy for Islamic countries is remarkable, given that Islamic ethics appear to be relatively skeptical on several forms of modern taxation. Obviously, the particularly close ties between religion and state in Islamic countries compensate for this. Largely, these significant findings only hold for countries with low or middle income so that the existence of a state religion in industrial countries is of no empirical relevance.

Of course, there are limitations to our analysis. Religion can be seen as a proxy for the cultural imprint of a country so that other dimensions of culture may stand behind the diagnosed impact of religion. Furthermore, it would be worthwhile to study the dynamics of the link. Unfortunately, the lack of time series for key religious variables for a large country would only allow such a study for a much smaller country sample.

Still, our findings already enrich the debate on the link between religion and economic development. Mobilizing sufficient resources for public infrastructure is one of the key challenges for developing countries. Our findings suggest that religions can be a partner for the secular government to achieve the normative backing for and acceptance of taxation. At least in this respect, a strong role for religion is no obstacle for economic development. 


\section{References}

Anderson, Gary M. and Robert D. Tollison (1992), Morality and Monopoly: The Constitutional Political Economy of Religious Rules, CATO Journal 13, 373-391.

Andreoni, James, Brian Erard and Jonathan Feinstein (1998), Tax Compliance, Journal of Economic Literature XXXVI (June), 818-860.

Barro, Robert J. and Rachel M. McCleary (2003), Religion and Economic Growth, American Sociological Review 68 (5), 760-781.

Becke, Andreas (1996), Hinduismus zur Einführung. Junius, Dresden.

Becker, Sascha O. and Ludger Woessmann (2009), Was Weber Wrong? A Human Capital Theory of Protestant Economic History, The Quarterly Journal of Economics 124 (2), 531-596.

Cohn, Gordon (1998), The Ethics of Tax Evasion: A Jewish Perspective, Journal of Accounting, Ethics and Public Policy 1, 109-120.

Cornelißen, Thomas (2006), Job Characteristics as Determinants of Job Satisfaction and Labour Mobility, Discussion Paper No. 334, Institute of Quantitative Economic Research, University of Hannover, Germany, 25.

D’Hernoncourt, Johanna and Pierre-Guillaume Méon (2008), The Not So Dark Side of Trust: Does Trust Increase the Size of the Shadow Economy? CEB Working Paper 08/030. Bruxelles, Centre Emile Bernheim.

Feld, Lars P. and Friedrich Schneider (2010), Survey on the Shadow Economy and Undeclared Earnings in OECD Countries, German Economic Review 11 (2), 109-149.

Finke, Roger and Laurence R. Iannaccone (1993), Supply-Side Explanations for Religious Change in America, The Annals of the American Academy of Political and Social Science 527, 27-39.

Fox, Jonathan (2004), Religion and State Codebook.

Fox, Jonathan and Ephraim Tabory (2008), Codebook for the Article "Contemporary Evidence Regarding the Impact of State Regulation of Religion on Religious Participation and Belief", Sociology of Religion 69 (3), 245-271.

Friedman, Eric, Simon Johnsonb, Daniel Kaufmannc and Pablo Zoido-Lobaton (2000), Dodging the Grabbing Hand: The Determinants of Unofficial Activity in 69 Countries, Journal of Public Economics 76, 459-493.

Furnham, Adrian (1983), The Protestant Work Ethic, Human Values and Attitudes Towards Taxation, Journal of Economic Psychology 3, 113-128.

Grasmick, Harold G. and Robert J. Bursik (1990), Conscience, Significant Others, and Rational Choice: Extending the Deterrence Model, Law and Society Review 24, 837860.

Hull, Brooks B. (2000), Religion Still Matters, The Journal of Economics 16 (2).

Huntington, Samuel Phillips (1997), The Clash of Civilizations and the Remaking of World Order, Simon \& Schuster, London.

Iannaccone, Laurence R. (1992), Sacrifice and Stigma: Reducing Free-Riding in Cults, Communes, and Other Collectives, Journal of Political Economy 100 (21).

Iannaccone, Laurence R. (1998), Introduction to the Economics of Religion, Journal of Economic Literature 36 (3), 1465-1495.

Keown, Damien (2005), Buddhist Ethics - a Very Short Introduction. Oxford University Press, New York.

Lindbeck, Assar (1995), Welfare State Disincentives with Endogeneous Habits and Norms, Scandinavian Journal of Economics 97 (4), 477-494.

Lindbeck, Assar, Sten Nyberg and Jörgen W. Weibull (1999), Social Norms and Economic Incentives in the Welfare State, Quarterly Journal of Economics 114 (1), 1-35. 
Mavrogordatos, George Th. (2000), Church-State Relations in the Greek Orthodox Case. "Church and State in Europe" ECPR Joint Sessions, 14-19 April 2000. Copenhagen.

McCullough, Michael E. and Brian L. B. Willoughby (2009), Religion, Self-Regulation, and Self-Control: Associations, Explanations, and Implications, Psychological Bulletin 135 (1), 69-93.

McGee, Robert W. (1997), The Ethics of Tax Evasion and Trade Protectionism from an Islamic Perspective, Commentaries on Law \& Public Policy 1, 250-262.

McGee, Robert W. (2006), Three Views on the Ethics of Tax Evasion, Journal of Business Ethics 67 (1), 15-35.

Olson, Daniel V.A. (1999), Religious Pluralism and U.S. Church Membership: A Reassessment, Sociology of Religion 60, 149-173.

Reckers, Philip M. J., Debra L. Sanders and Stephen J. Roark (1994), The Influence of Ethical Attitudes on Taxpayer Compliance, National Tax Journal 47 (4), 825-836.

Schneider, Friedrich, Andreas Buehn and Claudio E. Montenegro (2010), New Estimates for the Shadow Economies all over the World, International Economic Journal 24 (4), 443-461.

Schneider, Friedrich and Dominik H. Enste (2000), Shadow Economies: Size, Causes and Consequences, Journal of Economic Literature 38 (1), 77-114.

Sherkat, Darren E. and Christopher G. Ellison (1999), Recent Developments and Current Controversies in the Sociology of Religion, Annual Review of Sociology 25, 363-94.

Torgler, Benno (2006), The Importance of Faith: Tax Morale and Religiosity, Journal of Economic Behavior and Organization 61 (1), 81-109.

Vatican (1993), Catechism of the Catholic Church, Citta del Vaticano.

Voas, David, Daniel V.A. Olson and Alasdair Crockett (2002), Religious Pluralism and Participation: Why Previous Research Is Wrong, American Sociological Review 67, 212-230.

Whitford, David M. (2005), Martin Luther, Internet Encyclopedia of Philosophy. 


\section{Appendix}

Table A-1: Data definitions and sources

\begin{tabular}{|c|c|c|c|}
\hline Variable & Details & $\begin{array}{l}\text { Reference } \\
\text { year }\end{array}$ & Source \\
\hline \multicolumn{4}{|c|}{ Dependent variable and baseline controls } \\
\hline Size of the shadow economy & In \% GDP, see section 3.1 & 2000 & $\begin{array}{l}\text { Schneider, } \\
\text { Buehn and Mon- } \\
\text { tenegro (2010) }\end{array}$ \\
\hline GDP per capita in 1.000 & $\begin{array}{l}\text { Based on purchasing power pari- } \\
\text { ties, data are in constant } 2005 \\
\text { dollars }\end{array}$ & 2000 & $\begin{array}{l}\text { World Bank, } \\
\text { International } \\
\text { Comparison } \\
\text { Database }\end{array}$ \\
\hline Government effectiveness & $\begin{array}{l}\text { Perception based index from }-2.5 \\
\text { to }+2.5\end{array}$ & 2000 & $\begin{array}{l}\text { World Bank, see: } \\
\text { Schneider, } \\
\text { Buehn and Mon- } \\
\text { tenegro (2010) }\end{array}$ \\
\hline Size of government & $\begin{array}{l}\text { General government final con- } \\
\text { sumption expenditure in \% of GDP }\end{array}$ & 2000 & $\begin{array}{l}\text { United Nations, } \\
\text { World Bank, see: } \\
\text { Schneider, } \\
\text { Buehn and Mon- } \\
\text { tenegro (2010) }\end{array}$ \\
\hline Unemployment rate & \% of total labor force & 2000 & $\begin{array}{l}\text { International } \\
\text { Labor Organiza- } \\
\text { tion, World } \\
\text { Bank, national } \\
\text { sources, see: } \\
\text { Schneider, } \\
\text { Buehn and Mon- } \\
\text { tenegro (2010) }\end{array}$ \\
\hline Business freedom & $\begin{array}{l}\text { Subcomponent of Economic Free- } \\
\text { dom Index from } 0 \text { (least business } \\
\text { freedom) to } 100 \text { (maximum degree } \\
\text { of freedom) }\end{array}$ & 2000 & $\begin{array}{l}\text { Heritage Foun- } \\
\text { dation }\end{array}$ \\
\hline Fiscal freedom & $\begin{array}{l}\text { Subcomponent of Economic Free- } \\
\text { dom Index from } 0 \text { (least fiscal } \\
\text { freedom) to } 100 \text { (maximum degree } \\
\text { of freedom) }\end{array}$ & 2000 & $\begin{array}{l}\text { Heritage Foun- } \\
\text { dation }\end{array}$ \\
\hline Freedom from corruption & $\begin{array}{l}\text { Subcomponent of Economic Free- } \\
\text { dom Index from } 0 \text { (highest corrup- } \\
\text { tion) to } 100 \text { (no corruption) }\end{array}$ & 2000 & $\begin{array}{l}\text { Heritage Foun- } \\
\text { dation }\end{array}$ \\
\hline
\end{tabular}




\begin{tabular}{|c|c|c|c|}
\hline \multicolumn{4}{|c|}{ General religiosity } \\
\hline $\begin{array}{l}\text { Religion important (population } \\
\text { share), Gallup }\end{array}$ & $\begin{array}{l}\text { Population share in \% for which } \\
\text { "religion important part of daily } \\
\text { life" }\end{array}$ & 2010 & $\begin{array}{l}\text { Gallup World } \\
\text { Poll Website }\end{array}$ \\
\hline $\begin{array}{l}\text { Attending weekly (population } \\
\text { share), Gallup }\end{array}$ & $\begin{array}{l}\text { Population share in \% "attended a } \\
\text { place of worship or religious ser- } \\
\text { vice within the last seven days" }\end{array}$ & 2010 & $\begin{array}{l}\text { Gallup World } \\
\text { Poll Website }\end{array}$ \\
\hline $\begin{array}{l}\text { Confidence in religious organization } \\
\text { (population share), Gallup }\end{array}$ & $\begin{array}{l}\text { Population share in \% “having } \\
\text { confidence in religious organiza- } \\
\text { tions (churches, mosques, temples, } \\
\text { etc.)” }\end{array}$ & 2010 & $\begin{array}{l}\text { Gallup World } \\
\text { Poll Website }\end{array}$ \\
\hline Gallup religiosity indicator & $\begin{array}{l}\text { Average of preceding three Gallup } \\
\text { shares }\end{array}$ & 2010 & $\begin{array}{l}\text { Gallup World } \\
\text { Poll Website }\end{array}$ \\
\hline $\begin{array}{l}\text { Attending monthly (population } \\
\text { share), WVS/ISSP }\end{array}$ & $\begin{array}{l}\text { Attending religious services once a } \\
\text { month in \% }\end{array}$ & $\begin{array}{l}1995- \\
2000 \\
\text { mostly } \\
2000\end{array}$ & $\begin{array}{l}\text { Dataset Fox and } \\
\text { Tabory (2008), } \\
\text { originating from } \\
\text { WVS/ISSP }\end{array}$ \\
\hline $\begin{array}{l}\text { Attending weekly (population } \\
\text { share), WVS/ISSP }\end{array}$ & $\begin{array}{l}\text { Attending religious services once a } \\
\text { week in \% }\end{array}$ & $\begin{array}{l}1995- \\
2000 \\
\text { mostly } \\
2000\end{array}$ & $\begin{array}{l}\text { Dataset Fox and } \\
\text { Tabory (2008), } \\
\text { originating from } \\
\text { WVS/ISSP }\end{array}$ \\
\hline $\begin{array}{l}\text { Considering oneself religious (popu- } \\
\text { lation share), WVS/ISSP }\end{array}$ & $\begin{array}{l}\text { Self-assessment to be a "religious } \\
\text { person" "independently of whether } \\
\text { you go to church or not" in \% }\end{array}$ & $\begin{array}{l}1995- \\
2000 \\
\text { mostly } \\
2000\end{array}$ & $\begin{array}{l}\text { Dataset Fox and } \\
\text { Tabory (2008), } \\
\text { originating from } \\
\text { WVS/ISSP }\end{array}$ \\
\hline \multicolumn{4}{|c|}{ Specific religions } \\
\hline Majority religion dummies & see Table 1 & $\begin{array}{l}\text { around } \\
2000\end{array}$ & $\begin{array}{l}\text { RAS project, } \\
\text { Fox (2004) }\end{array}$ \\
\hline $\begin{array}{l}\text { Different religions’ population } \\
\text { shares }\end{array}$ & $\begin{array}{l}\text { RAS population \%-shares (dctotal, } \\
\text { ditotal, dototal, dnonetotal), con- } \\
\text { versions of missings into } 0 \text {, if } \\
\text { available shares add up to at least } \\
98 \%\end{array}$ & $\begin{array}{l}\text { around } \\
2000\end{array}$ & $\begin{array}{l}\text { calculated on the } \\
\text { basis of data } \\
\text { from RAS pro- } \\
\text { ject, Fox (2004) }\end{array}$ \\
\hline \multicolumn{4}{|c|}{ Religious fragmentation and competition } \\
\hline Population share majority religion & $\begin{array}{l}\text { Shares in \% relate to majority } \\
\text { religion as classified by majority } \\
\text { religion dummies }\end{array}$ & $\begin{array}{l}\text { around } \\
2000\end{array}$ & $\begin{array}{l}\text { RAS project, } \\
\text { Fox (2004) }\end{array}$ \\
\hline $\begin{array}{l}\text { Herfindahl index religions’ popula- } \\
\text { tion shares }\end{array}$ & $\begin{array}{l}\text { Herfindahl calculation, index } \\
\text { bound between } 0 \text { and } 1\end{array}$ & $\begin{array}{l}\text { around } \\
2000\end{array}$ & $\begin{array}{l}\text { Dataset Fox and } \\
\text { Tabory (2008) }\end{array}$ \\
\hline Dummy established state religion & One or more established religions, & 2000 & RAS project, \\
\hline
\end{tabular}




\begin{tabular}{|c|c|c|c|}
\hline & based on RAS variable sch2000 & & Fox (2004) \\
\hline \multicolumn{4}{|c|}{ Closeness religion and state } \\
\hline $\begin{array}{l}\text { Composite indicator on closeness } \\
\text { between religion and state }\end{array}$ & $\begin{array}{l}\text { RAS variable all2000, indicator } \\
\text { between } 0 \text { (strong separation) and } \\
100 \text { (fully religious state) }\end{array}$ & 2000 & $\begin{array}{l}\text { RAS project, } \\
\text { Fox (2004) }\end{array}$ \\
\hline $\begin{array}{l}\text { Dummy religious laws influence } \\
\text { legislation }\end{array}$ & $\begin{array}{l}\text { Legislation either "substantially } \\
\text { religious" or religious law is state } \\
\text { law, based on RAS variable } \\
\text { l1g2000 }\end{array}$ & 2000 & $\begin{array}{l}\text { RAS project, } \\
\text { Fox (2004) }\end{array}$ \\
\hline $\begin{array}{l}\text { Indicator discrimination against } \\
\text { minority religions }\end{array}$ & $\begin{array}{l}\text { RAS variable m2000, indicator } \\
\text { between } 0 \text { (no discrimination) and } \\
48 \text { (discrimination along all dimen- } \\
\text { sions) }\end{array}$ & 2000 & $\begin{array}{l}\text { RAS project, } \\
\text { Fox (2004) }\end{array}$ \\
\hline $\begin{array}{l}\text { Dummy mandatory religious educa- } \\
\text { tion }\end{array}$ & RAS variable lej2000 & 2000 & $\begin{array}{l}\text { RAS project, } \\
\text { Fox (2004) }\end{array}$ \\
\hline $\begin{array}{l}\text { Dummy government collects taxes } \\
\text { on behalf of religious organizations }\end{array}$ & RAS variable lfn2000 & 2000 & $\begin{array}{l}\text { RAS project, } \\
\text { Fox (2004) }\end{array}$ \\
\hline $\begin{array}{l}\text { Dummy government funding of } \\
\text { clergy }\end{array}$ & RAS variable lgn2000 & 2000 & $\begin{array}{l}\text { RAS project, } \\
\text { Fox (2004) }\end{array}$ \\
\hline
\end{tabular}

WVS: World Value Survey, ISSP: International Social Survey Program, RAS: Religion and State

Table A-2: Summary statistics baseline

\begin{tabular}{|c|c|c|c|c|c|}
\hline Variable & $\begin{array}{l}\text { Number of } \\
\text { observations }\end{array}$ & Mean & $\begin{array}{l}\text { Standard } \\
\text { deviation }\end{array}$ & Min & Max \\
\hline Size of the shadow economy in \% GDP & 161 & 33.75 & 13.04 & 8.60 & 67.30 \\
\hline GDP per capita in 1.000 USD & 154 & 11.27 & 12.82 & 0.26 & 62.16 \\
\hline Government effectiveness & 155 & 0.07 & 0.99 & -1.89 & 2.26 \\
\hline Size of government in \% GDP & 155 & 15.86 & 7.81 & 3.33 & 75.40 \\
\hline Unemployment rate in \% labor force & 163 & 8.92 & 6.19 & 0.00 & 32.44 \\
\hline Business freedom & 154 & 64.25 & 13.31 & 40.00 & 100.00 \\
\hline Fiscal freedom & 154 & 68.32 & 15.18 & 30.50 & 99.90 \\
\hline Freedom from corruption & 154 & 40.24 & 25.03 & 10.00 & 100.00 \\
\hline
\end{tabular}

